\title{
Multi-Scale Mass Transfer Processes Controlling Natural Attenuation and Engineered Remediation: An IFRC Focused on Hanford's 300 Area Uranium Plume
}

January 2011 to January 2012

Annual Report to the

DOE Office of Science, Climate and Environmental Sciences Division

\section{Principal Investigator:}

John Zachara, PNNL

\section{Co-Principal Investigators:}

Bruce Bjornstad, PNNL John Christensen, LBNL Mark Conrad, LBNL Jim Fredrickson, PNNL Mark Freshley, PNNL Roy Haggerty, OSU Glenn Hammond, PNNL Doug Kent, USGS Allan Konopka, PNNL
Peter Lichtner, LANL Chongxuan Liu, PNNL Jim McKinley, PNNL Chris Murray, PNNL Mark Rockhold, PNNL Yoram Rubin, U of CA, Berkeley Vince Vermeul, PNNL Roelof Versteeg, Sky Research Inc. Chunmiao Zheng, $U$ of $A L$

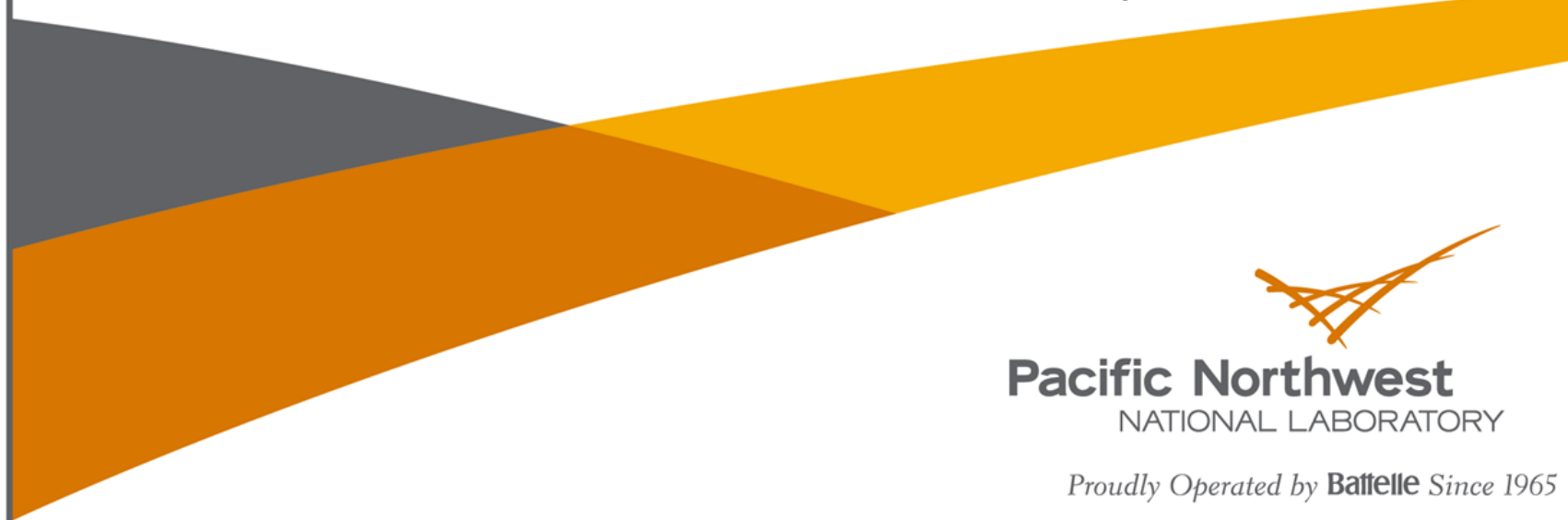




\title{
DISCLAIMER
}

This report was prepared as an account of work sponsored by an agency of the United States Government. Neither the United States Government nor any agency thereof, nor Battelle Memorial Institute, nor any of their employees, makes any warranty, express or implied, or assumes any legal liability or responsibility for the accuracy, completeness, or usefulness of any information, apparatus, product, or process disclosed, or represents that its use would not infringe privately owned rights. Reference herein to any specific commercial product, process, or service by trade name, trademark, manufacturer, or otherwise does not necessarily constitute or imply its endorsement, recommendation, or favoring by the United States Government or any agency thereof, or Battelle Memorial Institute. The views and opinions of authors expressed herein do not necessarily state or reflect those of the United States Government or any agency thereof.

\author{
PACIFIC NORTHWEST NATIONAL LABORATORY \\ operated by \\ BATTELLE \\ for the \\ UNITED STATES DEPARTMENT OF ENERGY \\ under Contract DE-AC05-76RL01830
}

Printed in the United States of America
Available to DOE and DOE contractors from the Office of Scientific and Technical Information,
P.O. Box 62, Oak Ridge, TN 37831-0062;
ph: (865) 576-8401
fax: $(865)$ 576-5728
email: reports@adonis.osti.gov

\begin{abstract}
Available to the public from the National Technical Information Service, U.S. Department of Commerce, 5285 Port Royal Rd., Springfield, VA 22161 ph: (800) 553-6847 fax: $(703) 605-6900$ email: orders@ntis.fedworld.gov online ordering: http://www.ntis.gov/ordering.htm
\end{abstract}

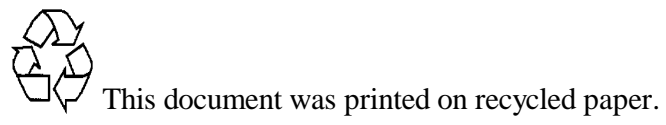




\section{Multi-Scale Mass Transfer Processes Controlling Natural Attenuation and Engineered Remediation: An IFRC Focused on Hanford's 300 Area Uranium Plume}

\section{January 2011 to January 2012}

Annual Report to the

DOE Office of Science, Climate and Environmental Sciences Division

J.M. Zachara, Principal Investigator

February 2012

Chemical \& Materials Sciences Division

Fundamental \& Computational Sciences Directorate

Pacific Northwest National Laboratory

Prepared for

the U.S. Department of Energy

under Contract DE AC05 76RL01830

Pacific Northwest National Laboratory

Richland, Washington 99352 


\section{Multi-Scale Mass Transfer Processes Controlling Natural Attenuation and Engineered Remediation: An IFRC Focused on Hanford's 300 Area Uranium Plume}

\section{Table of Contents}

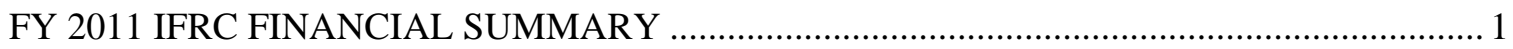

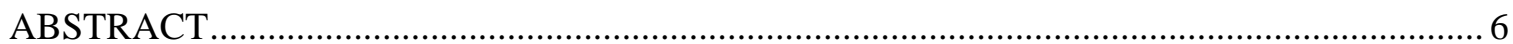

I. Project Status and Important Accomplishments...................................................... 7

II. Well Field Mitigation and Site Modifications ....................................................... 10

III. Characterization and Assimilation ............................................................................. 10

IV. Model of the Periodically Rewetted Lower Vadose Zone ........................................ 11

V. Passive Monitoring Associated with Water Table Fluctuation .................................. 12

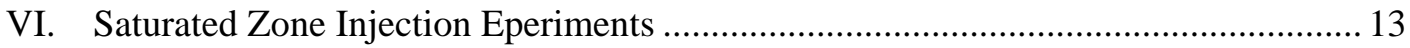

VII. MLS Biogeochemistry Experiment: Joint IFRC \& SFA Activities ............................ 16

VIII. Geophysical Monitoring of Infiltration and River Water Intrusion ........................... 16

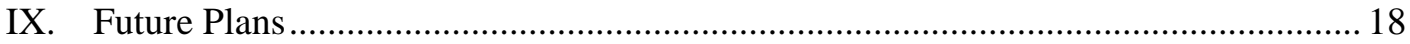

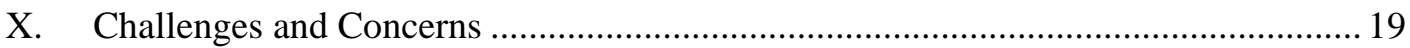

XI. Posters, Presentations, and Publications...................................................................... 19

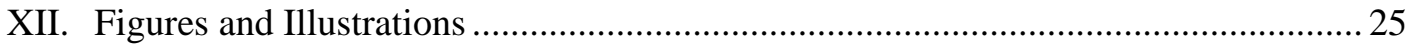




\section{Multi-Scale Mass Transfer Processes Controlling Natural Attenuation and Engineered Remediation: An IFRC Focused on Hanford's 300 Area Uranium Plume}

Annual Report: January 2011 - January 2012

\section{Principal Investigator:}

John Zachara, Pacific Northwest National Laboratory (PNNL) is IFRC Principal Investigator and primary contact with the SBR Program.

Field Site Manager:

Mark Freshley, PNNL, is field site manager and primary EM contact.

PNNL Co-Principal Investigators and Major Task (FY 2011 Funding):

Here we provide a financial synopsis for the Hanford IFRC for FY 2011. The synopsis is organized according to reporting categories in the quarterly and annual reports.

\section{FY 2011 IFRC FINANCIAL SUMMARY}

$\underline{\text { IFRC Funding Profile }}$

FY11 Project Funding:

\begin{tabular}{rr}
$\$$ & $3,000,000$ \\
$\$$ & 350,149 \\
\hline$\$$ & $3,350,149$ \\
\hline \hline
\end{tabular}

Total FY11 Funding:

\$ $2,970,089$

FY11 Spent:

$\$ 380,060 *$

Carryover to FY12:

* inlcudes $321 \mathrm{~K}$ in commitments

\section{Project Management - \$371,838,1,3}

John Zachara - (\$294,970), ${ }^{\mathbf{2}}$ - IFRC project manager and lead scientist. Responsible for Project success, reporting, financial management, productivity, and scientific accomplishment. Lead on all geochemical issues.

Mark Freshley - $(\mathbf{\$ 6 9 , 9 5 4})^{2}$ - Responsible for well and tracer permitting, development of field test plans, site operations including ES\&H, sample dispersement, QA/QC planning and review, and EM interactions.

Site Design and Installation - $\$ 226,014^{, 1,3,4}$ 
Mark Rockhold - $(\mathbf{\$ 9 , 4 4 6})^{, 6}$ - (Maintenance Monitoring) Overseas continuous water level monitoring network in the IFRC well-field and along the nearby river shore.

CHPRC Additional Well Drilling and Constructing - (192,109) - Installation of four new corner wells for improved estimates of hydraulic gradient and groundwater flow directions

Data Management - \$70,443,

Field Site Characterization and Data Assimilation - \$352,671, 1,3,10

Bruce Bjornstad - (\$31,670), ${ }^{\mathbf{6}}$ - Site Field Geologist. Responsible for development and upgrading of a site geologic facies model based on measurements and data collected during the well installation campaigns.

Tim Johnson - (\$181,268) ${ }^{\mathbf{6}}$ - Geophysical instrumentation, measurements, and modeling. Assisted by Jason Greenwood.

Chris Murray - (\$75,820) ${ }^{\mathbf{6}}$ - Geostatiscal Analysis of laboratory physical, geochemical, and hydrologic measurements, and results of field hydrologic characterization.

Vadose and Saturated Zone Experiments - \$718,388,3

Vince Vermeul - $\mathbf{( \$ 4 6 0 , 0 0 1})^{\mathbf{6}, 7}$ - Oversight and management of field hydrologic activities and monitoring systems, infrastructure, and injection experiments. Has determined the magnitude of intra-well vertical flows by direct measurement and is implementing mitigation. Performed four separate injection experiments with his team.

Mark Rockhold - $\mathbf{( \$ 1 3 0 , 6 0 5 )}{ }^{, 6}$ - Responsible for hydrologic data integration and transfer to others, and for modeling the results of hydrologic characterization and non-reactive tracer experiments.

Modeling and Interpretation Programs - \$966,394,

Chongxuan Liu - (\$24,854) - Responsible for the development of mass transfer models of $U$ adsorption and desorption at both the laboratory and field scales based on collaborations with Y. Fang (PNNL), C. Zheng (UA), D. Kent (USGS), and R. Haggerty (OSU).

Yilin Fang - (\$29,422), ${ }^{\mathbf{6}}$ - Stomp Modeling - Pre-modeling of field injection experiments and development of a smear zone reactive transport model.

Xingyuan Chen - $\mathbf{( \$ 7 6 , 6 6 4 )})^{, 6}$ - Former UCB student of Yoram Rubin. Integration of geochemical heterogeneity model into PFLOTRAN and stoichastic modeling of tracer experiments.

Glenn Hammond - $\mathbf{( \$ 3 0 , 4 7 1 )}{ }^{, 6}$ - PNNL expert on PFLOTRAN. Integration of geophysical measurements with hydrologic monitoring, and multiple realization simulations of the smear zone. Collaborates with Peter Lichtner (LANL).

\section{Passive Experimentation - \$264,340, 1,3}

Jim McKinley - (\$204,596) ${ }^{\mathbf{6}}$ - Design and oversight of all groundwater geochemical measurements, including the comprehensive monitoring experiments to evaluate seasonal $\mathrm{U}$ releases from the lower vadose zone. Assisted by Micah Miller, Tom Resch, and Rachael Lund. Leads in-situ biogeochemistry studies in collaboration with microbiologists Drs. Fredrickson and Konopka 


\begin{tabular}{|l|}
\hline 1. total dollars spent \\
\hline 2. dollars spent by individual and the adminis trative team \\
\hline 3. includes misc procurements, publication costs, travel or supplies \\
\hline 4. includes site support (see below) \\
\hline 5. includes subcontract to Sky Res earch (partial INL) - R. Versteeg \\
\hline 6. includes junior scientist labor \\
\hline 7. includes injection team members \\
\hline 8. includes external subcontracts to UCB, USGS, OSU, UA, LANL and LBNL \\
\hline 9. includes services from Rutgers (electrical measurement on cores) \\
\hline 10. ecological and cultural review \\
\hline
\end{tabular}

FY11 IFRC Subcontracts

\begin{tabular}{|l|l|r|r|}
\hline Vendor & Description & Trans Amt & Brdn Amt \\
\hline University of California Berkeley & Yoram Rubin & 210,000 & 232,729 \\
\hline US Geological Survey - LA & Doug Kent & 200,000 & 221,646 \\
\hline Central Hanford Plateau Remediation Co & Well Drilling/Site Services & 192,490 & 192,490 \\
\hline University of Alabama & Chunmiao Zheng & 111,000 & 123,014 \\
\hline Lawrence Berkeley National Laboratory & Mark Conrad and John Christensen & 112,535 & 112,535 \\
\hline Los Alamos National Laboratory & Peter Lichtner & 103,576 & 103,576 \\
\hline Sky Research Inc. (+ Bal of INL) & Roelof Versteeg & 64,893 & 70,582 \\
\hline Instrumentation Northwest, Inc. & Groundwater Sampling Pumps (dedicator pumps) & 19,453 & 21,584 \\
\hline Rutgers University & Low Frequency Complex Resistivity Measurements & 18,119 & 20,080 \\
\hline Central Hanford Plateau Remediation Co* & Provide field personnel and various support services during testing & 16,473 & 16,473 \\
\hline Rain for Rent & Two 21,000 gallon storage tanks for ground water & 9,173 & 10,166 \\
\hline Donald C. Girvin & 7,969 & 8,831 \\
\hline Instrumentation Northwest, Inc. & Groundwater sampling and analysis & 7,050 & 7,813 \\
\hline UT-Battelle, LLC & Sensors evaluation, reconditioning, and repair & 4,929 & 4,929 \\
\hline Williams Scotsman, Inc. & ORNL Sample Collection & 2,870 & 3,180 \\
\hline Other Miscellaneous & Storage and Equipment Container Units / Office Trailer & 1,421 & 1,507 \\
\hline Quantum Engineering Corporation & Other Miscellaneous & 700 & \\
\hline Oregon State University ** & EBF evaluation and repair & 776 \\
\hline & Roy Haggerty & $(14,366)$ & $(15,921)$ \\
\hline & & & \\
\hline & & $\mathbf{1 , 0 6 8 , 2 8 5}$ & $\mathbf{\$ 1 , 1 3 5 , 9 9 0}$ \\
\hline * Site support & Total & $\mathbf{\$}$ & \\
\hline ** OSU is behind on invoicing this is part of an accrual reversal & & \\
\hline & & &
\end{tabular}

\section{FY11 IFRC Procurements}

\begin{tabular}{|c|c|c|c|}
\hline Vendor & Description & TRANS_AMT & BRDN_AMT \\
\hline P-Cards & inlcude publication, lab supplies and misc costs & $\begin{array}{r}59,715 \\
\end{array}$ & 68,489 \\
\hline Fisher Scientific Company, LLC & Centrifuge Supplies/PT3 Test Supplies/Misc Lab Supplies & 29,643 & 33,999 \\
\hline Technology Integration Group & Geophysics Inversion and Enhanced Graphical Computational Computers & 11,863 & 13,606 \\
\hline Quantum Engineering Corporation & 220 and $250 \mathrm{Ft}$. Cable (watertight connector) and EBF system repair & 6,893 & 7,639 \\
\hline Pro-Seismic Services, LLC & Cables / 64 electrode / surface resistivity & 5,009 & 5,938 \\
\hline VWR International & UNIMAX Shakers & 4,910 & 5,631 \\
\hline $\mathrm{B} 2 \mathrm{~B}$ & Misc Supplies & 1,811 & 2,077 \\
\hline Atipa Technologies Inc & 4 computer nodes with dual socket 16 core AMD interlagos & 1,340 & 1,485 \\
\hline Miscellaneous Payments & Misc Payments & 1,323 & 1,445 \\
\hline & Total & 122,506 & 140,310 \\
\hline
\end{tabular}

\section{Key Collaborations:}

Harvey Bolton, John Zachara, Jim Fredrickson, Tim Scheibe, Chongxuan Liu, Alan Konopka, Chris Murray, and other PNNL, national laboratory (Scott Brooks, ORNL), Agency (Jim Davis, USGS), and 
university principle investigators (E. Roden, U. Wisconsin) collaborate through the PNNL SFA focused on Hanford-inspired subsurface science issues. Using IFRC site sediments, SFA investigators are: quantifying and modeling key microscopic reaction and transport processes (adsorption/desorption, precipitation/dissolution, mass transfer), implementing facies mapping and characterization for interpretation and assimilation of geophysical measurements, and characterizing microbiological distributions and function. The SFA team is also developing pore-scale biogeochemical reaction models of IFRC site sediments, and collaborating on in-situ microcosm experiments in IFRC site wells. SFA research is consequently providing essential information on IFRC site microbial ecology, microscopic reactive transport models, and geophysical characterization approaches.

A collaborative field biogeochemistry research task was initiated between the PNNL SFA and the Hanford SFA in 2011 involving P.I.'s Zachara, Fredrickson, Konopka, and McKinley and two post-docs. Research is investigating the biogeochemistry of the redox transition zone below the U plume, and seasonal microbial population and functional dynamics within the groundwater-river mixing zone.

Peter Lichtner (LANL) and Glenn Hammond (PNNL) collaborate through a SciDAC-2 project focused on high performance modeling of the 300 A plume. The project ends in FY 2011. Limited additional dollars are provided by the IFRC project $(\$ 200 \mathrm{~K})$.

Jon Fruchter, Dawn Wellman, and Vince Vermeul (PNNL) collaborate through the EM-20 Polyphosphate Demonstration Project, which performed one injection experiment in the saturated zone. The results of the injection test indicated that remediation of the uranium plume via autunite precipitation was unlikely to be feasible at the necessary scale. The EM-20 project is now pursuing an alternative strategy to remediate uranium in the smear zone by controlled infiltration of polyphosphate through the vadose zone. Our field experimental results have provided important insights on U(VI) resupply to and transport within the saturated zone that are informing revised remedial strategies for the groundwater plume.

Haluk Beyenal (Washington State University) and Jim Fredrickson (PNNL) collaborate on a SBR study of redox-controlling microorganisms in the 300 A unconfined aquifer. During FY 2011 this team inoculated flow cells and microcosms with IFRC site groundwater to initiate biofilm formation. The resulting biofilms were characterized by various microscopic methods and their influence on mineral/water biogeochemistry investigated.

Fred Day-Lewis (USGS), Andrew Binley (Lancaster University, UK), and Kamini Singha (Penn State University) are utilizing IFRC site infrastructure and sediments to investigate multi-scale mass transfer using geophysical methods. The SBR project was initiated in FY 2010, and the IFRC has provided the team with intact IFRC core samples in January 2010 to begin their research. The team plans a mass transfer field experiment at the IFRC in the summer of FY 2012.

William Burgos (Penn State University), Hailang Dong (University of Miami, OH), and Ken Kemner $\underline{(\mathrm{ANL})}$ are investigating biogeochemical redox reactions of uranium and oxygen with Fe-containing layer silicates from the IFRC site in SBR research. Bulk samples of Fe(II)-containing smectites from the IFRC Ringold Formation were provided to the research team in November 2010.

CHPRC and Hanford RL have relied on the Hanford IFRC as the sole source of new scientific findings and system scale understanding of the complex behaviors of the $300 \mathrm{~A} \mathrm{U}$ plume. A site remediation 
subcontractor (INTERA) utilized IFRC research results and publications along with our guidance and recommendations to develop a new simulator to forecast the duration of plume persistence. Additionally, IFRC project personnel wrote the new conceptual model document for the 300 A plume that formed the basis for the recently released RI/FS report to the USEPA ("Proposed Plan for the Remediation of 300FF-1, 300-FF-2, and 300-FF-5 Operable Unites" - DOE/RL-2011-47). Scientific findings from IFRC site research enabled major revisions to the conceptual model. 


\begin{abstract}
The Integrated Field Research Challenge (IFRC) at the Hanford Site 300 Area uranium (U) plume addresses multi-scale mass transfer processes in a complex subsurface biogeochemical setting where groundwater and riverwater interact. A series of forefront science questions on reactive mass transfer motivates research. These questions relate to the effect of spatial heterogeneities; the importance of scale; coupled interactions between biogeochemical, hydrologic, and mass transfer processes; and measurements and approaches needed to characterize and model a mass-transfer dominated biogeochemical system. The project was initiated in February 2007, with CY 2007, CY 2008, CY 2009, and CY 2010 progress summarized in preceding reports. A project peer review was held in March 2010, and the IFRC project acted upon all suggestions and recommendations made in consequence by reviewers and SBR/DOE. These responses have included the development of "Modeling" and "Well-Field Mitigation" plans that are now posted on the Hanford IFRC web-site, and modifications to the IFRC wellfield completed in CY 2011.
\end{abstract}

The site has 35 instrumented wells, and an extensive monitoring system. It includes a deep borehole for microbiologic and biogeochemical research that sampled the entire thickness of the unconfined $300 \mathrm{~A}$ aquifer. Significant, impactful progress has been made in CY 2011 including: i.) well modifications to eliminate well-bore flows, ii.) hydrologic testing of the modified well-field and upper aquifer, iii.) geophysical monitoring of winter precipitation infiltration through the U-contaminated vadose zone and spring river water intrusion to the IFRC, iv.) injection experimentation to probe the lower vadose zone and to evaluate the transport behavior of high U concentrations, v.) extended passive monitoring during the period of water table rise and fall, and vi.) collaborative down-hole experimentation with the PNNL SFA on the biogeochemistry of the 300 A Hanford-Ringold contact and the underlying redox transition zone. Collaborative microbiologic studies with the PNNL SFA have established a census of microorganism types present with the IFRC with research now evolving to investigations of in-situ function and activity. The modified well-field has functioned superbly without any evidence for wellbore flows. Beyond these experimental efforts, our site-wide reactive transport models (PFLOTRAN and eSTOMP) have been updated to include site geostatistical models of both hydrologic properties and adsorbed $U$ distribution; and new hydrologic characterization measurements of the upper aquifer. These increasingly robust models are being used to simulate past and recent $\mathrm{U}$ desorption-adsorption experiments performed under different hydrologic conditions, and heuristic modeling to understand the complex functioning of the smear zone. We continued efforts to assimilate geophysical logging and 3D ERT characterization data into our site wide geophysical model, with significant and positive progress in 2011 that will enable publication in 2012.

Our increasingly comprehensive field experimental results and robust reactive transport simulators, along with the field and laboratory characterization, are leading to a new conceptual model of U(VI) flow and transport in the IFRC footprint and the 300 Area in general, and insights on the microbiological community and associated biogeochemical processes influencing N, S, C, Mn, and Fe. Collectively these findings and higher scale models are providing a unique and unparalleled system-scale understanding of the biogeochemical function of the groundwater-river interaction zone. 


\section{PROJECT STATUS AND IMPORTANT ACCOMPLISHMENTS}

Project activities in FY 2011 were primarily focused on: i.) modifying the IFRC well field to eliminate vertical borehole flow, ii.) hydrologic testing to validate mitigation effectiveness and to characterize the now isolated upper aquifer, iii.) passive and active experimentation on U(VI) transport, iv.) geophysical monitoring of meteoric water infiltration and river water intrusion, and v.) joint biogeochemical studies of the Hanford-Ringold contact and underlying redox transition zone below the U(VI) plume in collaboration with the PNNL SFA. Our project status is summarized in Figure 1. Overall, progress has been excellent as shown by completed activities in FY 2011 (e.g., blue). This progress has supported a number of presentations, posters and publications (see PRESENTATIONS, POSTERS, and PUBLICATIONS).

\section{Important Activities and Findings}

- Well-field mitigation activities were completely successful, yielding a groundwater monitoring system that produces high quality data free of vertical flow artifacts. Field hydrologic characterization of the upper aquifer was performed and completed.

- Data assimilation activities have continued with the objective to establish a robust integrated hydrophysical model of the IFRC subsurface domain that reflects a variety of field and laboratory measurements performed over a range in scale.

- Multi-investigator laboratory experimentation with the IFRC smear zone composite has enabled the development of a robust reactive transport model of the periodically rewetted lower vadose that serves as a dynamic U(VI) source to the plume. The model is being used for heuristic modeling studies to understand the complex effects of process coupling on $\mathrm{U}$ release, and to simulate passive monitoring results of $U$ solubilization during spring high-water.

- Passive monitoring of the IFRC well-field has documented U solubilization from the lower vadose zone during periods of high river stage that recharges the groundwater plume. Three separate years of monitoring data from the same individual wells has revealed complex temporal dynamics for $\mathrm{U}$ concentration that result from variations in year-to-year hydrologic conditions. A multivariate statistical analysis of this data is underway to identify key hydrologic and geochemical factors controlling the overall, system-scale response.

- Multiple injection experiments with high and low U into the IFRC site domain (four being performed in 2011) have collectively revealed that U(VI) retardation is very low in the saturated zone under ambient groundwater conditions. Groundwater concentration variations that occur under these ambient conditions result solely from temporally dynamic lower vadose zone recharge events. However, the transient geochemical conditions that occur with river water intrusion enhance retardation by factors of 2-3 and increase mass transfer effects. River intrusion events cause distinctive changes to the groundwater plume that exhibit "memory effects" because of the kinetic nature of the geochemical process.

- Solute and dissolved gas monitoring across the Hanford-Ringold contact at the base of the U plume using a multi-level diffusion cell sampler deployed in select IFRC wells has revealed the 
existence of a deeper biogeochemically active zone where various terminal electron acceptors are used and depleted including oxygen, nitrate, manganese (III/IV), iron (III), and sulfate. Reduced products of anaerobic metabolism including nitrous oxide, methane, and hydrogen gas diffuse upward from this active zone into overlying oxic groundwaters that host the U(VI) plume.

- Surface geophysical measurements by ERT have shown great promise in monitoring the complex temporal dynamics and heterogeneity of both meteoric water infiltration and river water intrusion into the IFRC subsurface environment. A better quantification of these hydrologic vectors is necessary to forecast $\mathrm{U}$ flux from the vadose zone, and predict groundwater compositional changes resulting from river water intrusion and mixing.

\section{Current Status}

At the time of this report writing (2/2012) all ongoing IFRC experimental activities have been terminated, and remaining project resources are being directed toward i.) analysis of field samples collected in the fall 2011 experimental campaign, ii.) data assimilation activities, iii.) field experiment and smear zone modeling, and iv.) manuscript preparation.

In the text that follows we will summarize select results of 2011 research targeting the activities and findings noted above. Our intent is not to be exhaustive, but to be informative in a concise manner. A Hanford IFRC poster session at the SBR Annual Meeting in April 2012 will describe additional findings. 


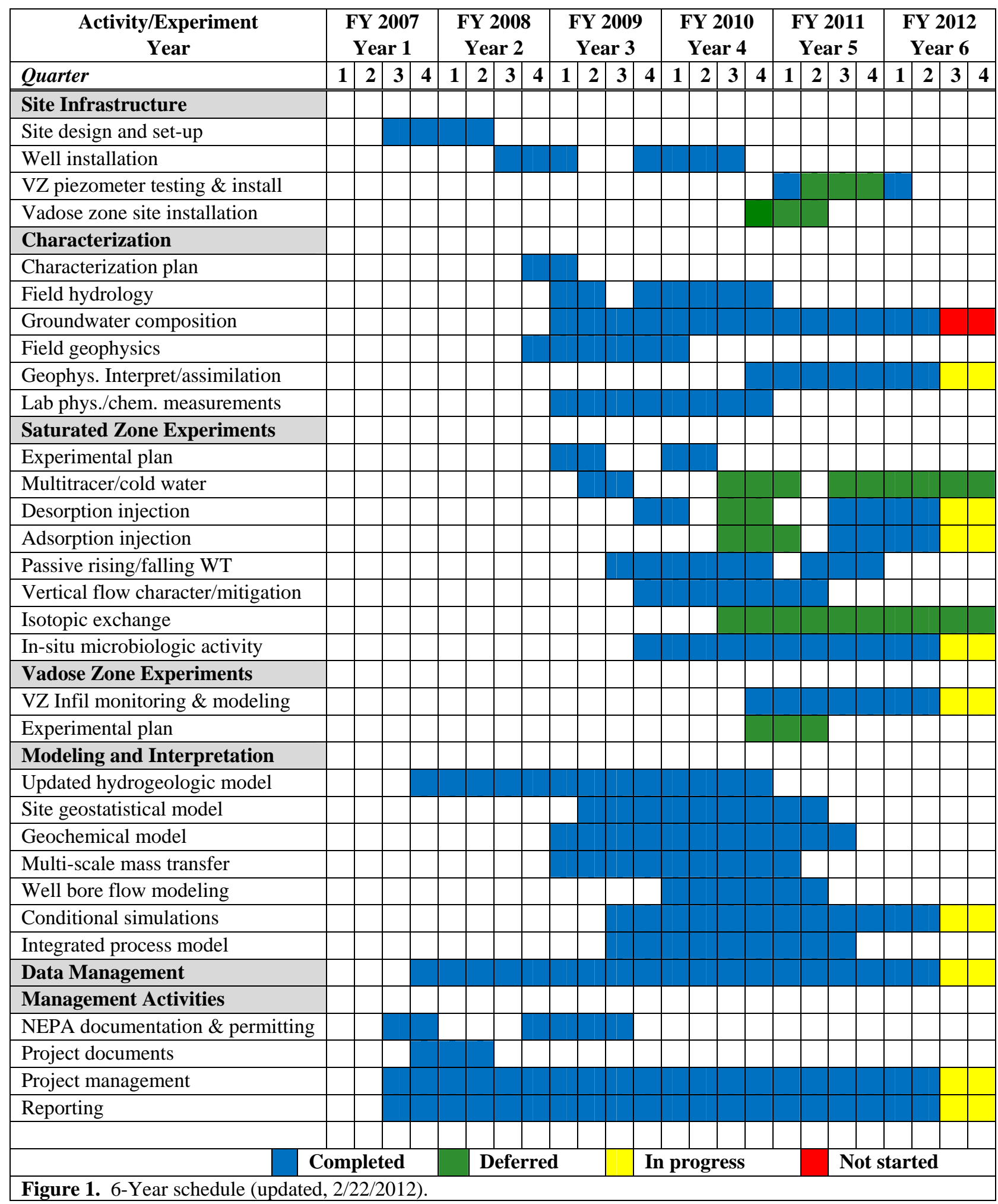




\section{WELL FIELD MITIGATION AND SITE MODIFICATIONS}

\section{Well Remediation Activities}

The lower $66 \%$ of all of the fully screened wells (lower high $\mathrm{K}$ and intermediate low K zones) were sealed with bentonite in January 2011 to eliminate vertical borehole flows, except two wells (399-3-24 and 399-3-27) in the SE corner of the well-field that are used for ongoing collaborative biogeochemistry studies with the PNNL SFA. Bentonite addition was carefully monitored so it would not invade the upper aquifer zone or it's well screen.

\section{Upper Zone Hydrologic Characterization}

Once wellbore flow mitigation activities were completed (February 2011), additional hydrologic characterization of the well-field was performed. This field testing campaign was done to better quantify the bulk hydraulic conductivity, and its vertical distribution, within the upper aquifer. Previous hydraulic characterization activities were performed over the full aquifer thickness. Because the lower zone was highly permeable and thus tended to dominate the response, hydraulic property estimates for the upper aquifer are somewhat uncertain. All IFRC wells were surveyed by electromagnetic borehole flowmeter (EBF) at approximate $15 \mathrm{~cm}$ depth intervals before well field mitigation and then again after the wells had stabilized following bentonite addition. Constant rate injection tests were performed in all wells that received bentonite treatment.

\section{Hydrology Control Wells}

Four new far-field groundwater monitoring wells were installed around the perimeter of the IFRC site in March 2011 to provide improved hydraulic head measurements for modeling water flow and solute transport within the IFRC site. The wells are instrumented with pressure transducers for continuous monitoring of water table elevation and were functional during the March 2011 desorption experiment, and the fall 2011 experiment series. Among other things, these wells have helped to further define the regional hydraulic gradient, and the paleo-channel feature that runs through the IFRC well-field, as well as the amount of relief (up to $27 \mathrm{ft}$ ) on the Ringold aquitard in the vicinity of the site. Regional data from the 11 new 300 Area RI/FS wells has also been integrated into the IFRC/300A hydrogeologic model. Core samples from the four new wells were provided to the PNNL SFA for microbiologic research.

\section{CHARACTERIZATION AND ASSIMILATION}

\section{Hydrophysical Data Assimilation}

The data assimilation task has continued to integrate new site characterization measurements as they became available in 2011 to improve the IFRC site hydrophysical and hydrochemical models. The new hydrologic data described above were assimilated into the site-wide hydraulic conductivity model using the Method of Anchored Distributions (MAD), the theoretical framework and associated numerical model that has been developed for Hanford IFRC data assimilation and inverse modeling (Rubin et al., 2010). Figure 1 compares hydraulic conductivity distributions developed using the previous (2009) and the revised (2011) EBF profiles. Profound differences have been observed in terms of the continuity of the 
low-conductivity layer at mid-section, and a reduction in the conductivity of the high conductivity layers above and below. The improved results were a consequence of understanding the well-bore flow problem. These new results were used in revised simulations of the March 2009 injection experiment that was recently accepted for publication, and for ongoing modeling of CY 2011 injection experiments.

\section{Geophysical Data Assimilation and Interpretation}

An extensive 3-D cross-hole electrical resistivity tomography (ERT) dataset was collected within the IFRC well field prior to vertical wellbore flow mitigation. This dataset has been analyzed by tomographic inversion to yield the 3D distribution of the direct-current electrical conductivity structure of the IFRC well-field from the ground surface to the Hanford/Ringold contact. Initial efforts to analyze these data using a standard smoothness-constrained imaging approach were only slightly successful, being highly influenced by borehole effects, sharp conductivity contrasts at the water table and Hanford/Ringold contact, and variable imaging resolution between boreholes. To address these issues, the imaging code was modified with a series of physical constraint improvements including sharp contrasts at conductivity boundaries, explicit modeling of boreholes, and the integration of core measurements and geostatistical information derived from logging data. The improvements were implemented with cluster computing capability allowing a single inversion of the entire dataset using high performance computing resources. The final imaging results (Figure 2) display a significant improvement over the standard inversion with properties variations consistent with physical characterization measurements.

Although subsurface electrical conductivity is governed by parameters that are important for predicting solute transport behavior at the IFRC (e.g. clay content, ionic strength, porosity, saturation), quantitatively extracting these parameters from the ERT imaging results in Figure 2 using a petro-physical relationship is problematic. The imaging approach developed here aims to identify 'electrofacies', or spatially continuous and geostatistically accurate electrical conductivity structures that have been defined by the analysis of intact cores in the laboratory. These parameters are then mapped to the well field through the corresponding ERT-derived electrofacies, assuming the spatial correlation structure of each derived parameter is consistent with the corresponding spatial correlation of electrical conductivity. This mapping is made possible by constraining the imaging inversion to honor known conductivity values derived from core measurements, and fixing the spatial covariance structure to be equal to that determined by other characterization activities. The imaging results produced by this approach were driven by complex resistivity measurements performed by Rutgers University on six well-field cores taken from strategic locations, and with spatial covariance structure derived from borehole logging measurements. The final results for the saturated zone show good correlation with borehole flow-meter logging data of hydraulic conductivity (Figure 3), suggesting promise in the use of ERT data to further condition the IFRC permeability field.

\section{MODEL OF THE PERIODICALLY REWETTED LOWER VADOSE ZONE}

A multi-investigator team including the USGS, Oregon State University, and PNNL has developed an extensive and coordinated multi-scale experimental data base on U(VI) desorptive release from the IFRC smear zone composite sediment. This composite was created by mixing smear zone core samples from 17 IFRC wells. The data set is robust and includes flow cell experiments of various sediment size fractions, and unsaturated and saturated column experiments of repacked sediment with variable amounts of gravel. 
All of the data was integrated into a single data set that was fit with a common reaction network including a multi-rate, kinetic surface complexation model. The reaction network included microbial respiration and nitrate reduction that were observed to occur in the column experiments and effect U(VI) speciation and transport. The reaction network and kinetic surface complexation model have been incorporated into our IFRC site simulators, PFLOTRAN and ESTOMP.

The multiple realization capability in PFLOTRAN is being used to evaluate the effects of key variables on $U$ mobilization from the smear zone, including water table elevation and fluctuation rate, sorbed $U$ concentration distribution, and dispersion anisotropy. Uranium fluxes to groundwater have been found to be extremely sensitive to Columbia River hydrologic conditions that vary dramatically on a year to year basis. The model is also being used to simulate the results of passive spring monitoring where large increases in groundwater U(VI) have been observed in select IFRC wells when the water table has advanced into the lower vadose zone (see next section). Another application has been to explore how long the smear zone may continue to function as a source to the plume given its current, measured concentration of adsorbed U(VI) (Figure 4). In this simulation 2010 hydrologic conditions were propagated for $12 \mathrm{y}$. The model (based on measured, adsorbed U(VI) concentrations in the smear zone composite) calculates very high U(VI) concentrations in smear zone porewater (e.g., >> 200 ppb, panel 1) that increase groundwater concentrations to between 100 and $150 \mathrm{ppb}$ (panel 3) over the first 4 years. These values are quite similar to observed values at the IFRC. It also indicates that after $12 \mathrm{y}$ groundwater concentrations are still likely to exceed the MCL of $30 \mathrm{ppb}$. Science-based calculations of this nature provide important insights on whether costly remediation should or should not be pursued. Note however, the smooth decreases in modeled aqueous and adsorbed concentrations would show far greater variability if reasonable year-to-year variations in Columbia River stage were considered. Ongoing simulations will incorporate this complexity.

\section{PASSIVE MONITORING ASSOCIATED WITH WATER TABLE FLUCTUATION}

Daily water quality monitoring of the IFRC well field was initiated in April 2011 and continued to July 1, 2011. The objectives of the monitoring were twofold: 1.) to confirm for the third consecutive year that the high spring water table solubilizes $U$ from the lower zone and sustains $U$ concentrations in the plume and 2.) to identify the peak $U$ concentration in groundwater that could be sampled in large volume to support a fall, 2011 high $\mathrm{U}$ injection experiment. These objectives were accomplished in full, with 40,000 gallon of groundwater containing $1200 \mu \mathrm{g} / \mathrm{L}$ of U(VI) sampled and placed into storage.

The 2010 and 2011 water table elevations and conductivity results are plotted in Figure 5 for Well 2-24, which is located at the eastern edge of the well field. For elevation, the measurements at a per-day resolution were uniform across the well field, and could be represented by results from a single well. Data were collected at a resolution of seconds using down-hole pressure transducers and those data were used to calculate hydraulic gradients across the site. For Figure 5, daily data at a single time point - 9:00 a.m. - were selected and plotted. In 2011, the water table remained relatively constant during April, then rose steadily from early May and into early June, then declined through the month of July. The rise was earlier and reached a significantly higher elevation than in 2010. The water table rise corresponded directly to rises in river stage (not shown). River water intruded to the IFRC, appearing as a mixing front evident from changes in electrical conductivity (Figure 5). In contrast to the 2010 effect of river water, the intrusion during 2011 represented a larger river water component within the aquifer. The contrast in 
groundwater-river water composition provided an estimated river water component in 2010 of ca. $80 \%$ with an equivalent calculation in 2011 indicating river water in excess of $95 \%$. In addition, the river water intrusion during 2011 was more persistent, as indicated by the broader duration of low-conductivity values (Figure 5). The river water component was proportionately less across the IFRC, east to west, reflective of increasing distance from the river shore.

Uranium concentrations varied across the IFRC during the period of river water rise (Figures 6 and 7). Figure 6 compares $U$ concentrations in Well 2-26, the shallow-completion well located at the northern three-well cluster. In 2010, U was contributed to the aquifer at that location during the highest water table excursion (i.e., early July, Figure 6), suggesting that the water table reached a zone of $U$ within the vadose zone that was at high elevation compared to the elevation of the water table during the low-water period. In 2011, the U concentration at well 2-26 was decreased during June, due to dilution by river water, and showed a more gradual rise as river water retreated during July. Little river water reached the northern IFRC in 2010, and the river water component of groundwater evident during 2011 may have masked U contributions. The rise in $\mathrm{U}$ concentrations during the period of water table lowering may reflect dispersion of $U$ across the IFRC; the analysis of these results is incomplete, and requires complete, fieldwide results for evaluation.

Uranium concentrations were highest near the southern three well cluster, represented by well 3-30 (Figure 7). In 2010, U concentrations increased immediately with the rise in water table, to a maximum of ca. $320 \mu \mathrm{g} / \mathrm{L}$, then fluctuated and decreased rapidly with the water table. In 2011, in contrast, the U concentration increased to approximately the same value as in $2010(300+\mu \mathrm{g} / \mathrm{L})$, but spiked and decreased rapidly. As with well 2-26, the decrease in U concentrations may have been, in part, a result of dilution with influent river water. In July 2011, the U concentration increased and remained elevated above low-water background (ca. 50-60 $\mu \mathrm{g} / \mathrm{L}$ ) during the remainder of the monitoring period (into August 2011). Again, the behavior over time of the $U$ concentrations is incomplete and requires a more generalized interpretation of results from across the IFRC.

The results collectively indicate that the influx of Columbia River water into the IFRC varies yearly in response to the dynamics of basin-wide snow melt. The geochemical environment in high-stage years can vary from ambient ground water to $\sim 100 \%$ river water, with significant effects on cation complexation (e.g., uranyl-carbonate complexes), and on microbial community makeup and activity. The results also indicate a significant impact of water table intrusion on the vadose zone, with $U$ concentrations changing in response to $\mathrm{U}$ capture from the vadose zone into the aquifer, and in response to mixing with invading, dilute river water.

\section{SATURATED ZONE INJECTION EPERIMENTS}

\section{Spring 2011 Low U(VI) Desorption Experiment}

A U(VI) desorption experiment was performed in the upper high $\mathrm{K}$ zone during late March to May, 2011. The experiment was planned through extensive STOMP pre-modeling and involved the injection of 220,000 gallon of low $\mathrm{U}$ concentration groundwater (with $\mathrm{Cl}^{-}$and deuterium tracer) over a two week period (3/25/2011 to 4/9/2011). The experimental objective was to create an extended zone of low $U$ concentration groundwater through the center of the IFRC that would induce desorption of adsorbed U from the aquifer sediments. We expected that the advancing front of returning native groundwater would 
display retardation as depleted adsorption sites were refilled by $\mathrm{U}$ in ambient site groundwater. During the experiment, there was continuous pressure and down-hole specific conductance monitoring at select well locations followed by a month of daily aqueous sampling from all well locations yielding over 1000 samples for analysis. The analysis of all samples has been recently completed (e.g., Figure 8), and subjected to QA/QC assessment. The data set showed no evidence of artifacts from well-bore flows, indicating that well field mitigation was successful. Modeling of the data set has now begun by teams using both PFLOTRAN and e-STOMP to evaluate different objectives. A poster was presented on these results at the winter AGU meeting.

Unpredicted heavy rains on a heavy snowpack throughout the Columbia River watershed began soon after the initiation of the experiment that caused a surge in river discharge that impacted the performance of the experiment. While our data set is robust and comprehensive, it is complex, displaying the effects of multiple reversals in groundwater flow direction and advance of the water table into the U-enriched smear zone before the traditional period of water table advance (see Figure 8).

Significant efforts are underway to model the March 2011 desorption injection experiment. As previously described, this experiment was a slow $(10 \mathrm{gpm})$, long-term $(353 \mathrm{~h})$ injection experiment with low U(VI) groundwater $(6.2 \mu \mathrm{g} / \mathrm{L})$ intended to create an extended zone of desorbed U(VI) through the central domain of the IFRC well field. The experiment encountered very dynamic groundwater flow conditions as a result of unusual weather conditions. The low $\mathrm{U}$ injection plume was pushed up into the smear zone several times during the injection experiment by sustained high Columbia River stage, leading to multiple events of vadose zone U(VI) mobilization that were observed to varying degree throughout the well field.

Modeling has used the PFLOTRAN code and its multi-realization capability to assess the influence of hydrologic and geochemical uncertainty on the ability to describe the complex tracer and U(VI) breakthrough curves that were obtained from the experiment. The hydrologic uncertainties evaluated were flow boundary conditions and the permeability field; and the geochemical uncertainties were initial $\mathrm{U}(\mathrm{VI})$ groundwater concentrations, sorbed U(VI) distribution in the vadose zone, and adsorption site concentrations and distribution. The geochemical uncertainties were evaluated using realizations of the permeability field that best reproduced the non-reactive tracer data.

The model simulations were performed on the Jaguar supercomputer. They were indeed massive as they included multiple 3D realizations of both the permeability field and U(VI) distribution in a 432,000 cell grid. It is the first time that our 3D geostatistical model of sorbed U(VI) distribution has been included in reactive transport calculations. The results affirmed the critical role of sorbed $\mathrm{U}(\mathrm{VI})$ distribution and release rate on $\mathrm{U}(\mathrm{VI})$ concentrations in this injection experiment that entered the smear zone.

\section{Fall 2011 High U(VI) Injection Experiments}

A series of uranium adsorption/desorption experiments were conducted in October through December, 2012 with the objective of providing information about uranium mass transfer processes and kinetics for high concentration U(VI) pulses released from the lower vadose zone. Two primary hypotheses were evaluated: i.) $\mathrm{U}(\mathrm{VI})$ retardation would increase in the river water matrix because of the reduced effects of carbonate complexation, and ii.) mass transfer effects and retardation would increase in the lower permeability zone because of higher mud content. The initial results are very encouraging and the project 
team anxiously awaits completion of the entire data-set which is being processed. To this end, a series of three injection experiments were performed using 40,000 gallons of high $\mathrm{U}$ groundwater that was collected in the spring of 2011, and stored on site over the summer. The collected groundwater contained $1700 \mu \mathrm{g} / \mathrm{L}$ of $\mathrm{U}(\mathrm{VI})$ that was diluted approximately 3-fold for injection. Three different tracers were used to discern the injection experiments. Experiment 1 injected 45,000 gallon of groundwater containing 600 $\mu \mathrm{g} / \mathrm{L} \mathrm{U}(\mathrm{VI})$ and $\mathrm{Br}^{-}$tracer into the upper aquifer. Experiment 2 injected 47,000 gallon of filtered river water containing $570 \mu \mathrm{g} / \mathrm{L} \mathrm{U}(\mathrm{VI})$ and $\mathrm{Cl}^{-}$tracer into the upper aquifer. Experiment 3 injected 21,000 gallon filtered river water containing $750 \mu \mathrm{g} / \mathrm{L} \mathrm{U}(\mathrm{VI})$ and $\mathrm{F}^{-}$tracer into the lower permeability, intermediate zone of the aquifer using well 399-2-28. Based on previous characterization activities at the site, and a previous injection experiment, this well is known to be completed over a depth interval comprised of relatively low permeability material that is both over and underlain by higher permeability materials. Although depth discrete aqueous monitoring locations were limited to the injection well and the upper and lower zone wells at this location, this single three-well cluster did provide a means for assessing both escape of tracer from the targeted zone during the injection phase and elution of tracer from the targeted zone during the drift phase of the experiment. An operational summary for the three injection tests is provided in Table 1. It should be noted that all reported values are preliminary estimates that may change based on ongoing aqueous sample analyses and data interpretation.

Table 1. Fall 2011 Uranium Adsorption/Desorption Experiment Operational Summary

\begin{tabular}{|l|c|c|c|}
\hline Parameter & Experiment 1 & Experiment 2 & Experiment 3 \\
\hline Injection well & $2-34$ & $2-34$ & $2-28$ \\
\hline Injection volume (gallons) & 45,000 & 47,000 & 21,000 \\
\hline Tracer anion & $\mathrm{Br}^{-}$ & $\mathrm{Cl}^{-}$ & $\mathrm{Fl}^{-}$ \\
\hline Tracer concentration $(\mathrm{mg} / \mathrm{L})$ & 100 & 100 & 100 \\
\hline Uranium concentration injected $(\mu \mathrm{g} / \mathrm{L})$ & 600 & 570 & 750 \\
\hline Injection Rate $(\mathrm{gpm})$ & 150 & 145 & 25 \\
\hline Injection Duration (hours) & 5 & 5.4 & 13 \\
\hline Injection Start Date/Time & $10 / 1911: 00$ & $10 / 2710: 35$ & $11 / 179: 00$ \\
\hline
\end{tabular}

The hydraulic gradient was of similar nature during each of the first two experiment (Figures 9 and 10). For the first 200 hours of each experiment, the gradient ranged from approximately 0.0001 to 0.00075 $\mathrm{m} / \mathrm{m}$. The azimuth during this period was relatively constant at approximately 120 degrees from true north. During both experiments there was a sharp decrease in gradient about 24 hours after the start. The decrease in gradient coincided with a similar decrease in the measured uranium concentration at the injection well (2-34; Figure 9) and the closest downgradient upper zone monitoring well (2-26; Figure 10). At 2-26 the decrease was more dramatic. At both locations, the uranium concentrations appeared to decrease more rapidly in the second experiment (river water type composition), but then remained slightly elevated for a longer period of time, resulting in an extended tail on the uranium elution curve. Analytical results for anions and major cations are not yet available to inform the evaluation, but given the similarity in the hydraulic gradient between the two experiments, this observed uranium behavior is likely associated with increased uranium sorption/desorption processes during the second injection.

Results from the third injection experiment, which was conducted in the lower permeability intermediate zone, clearly demonstrate the effects of uranium sorption processes within this lower permeability material (Figure 11). It is unclear why both the specific conductance and uranium drop so quickly at the 
end of the injection period and whether this response was controlled by the same processes influencing the early-time responses in the two upper zone wells. A comprehensive evaluation based on the full suite of measured analytes (U, anions, major cations, carbon), which will be conducted once analytical results are available, should provide additional insights into these results. While the specific conductance did rebound to some extent about 90 hours after the end of the injection, overall the specific conductance remained much lower than that of the injection solution, and decreased slowly over time. Conversely, following the initial decrease in uranium concentration, values steadily increased to well above the injection concentration. After the initial decrease, the uranium concentration increased between about 100 and 400 hours and then leveled off, and has remained elevated as of the latest sampling event (40+ days). The observed uranium response at well 2-28 may be associated with increased uranium sorption in the presence of low bicarbonate concentration waters during the injection period, followed by increased bicarbonate concentrations as injected waters equilibrated with aquifer sediments and groundwater migrated back into the injection zone. This well will continue to be monitored until the uranium concentration returns to pre-injection baseline levels.

\section{MLS BIOGEOCHEMISTRY EXPERIMENT: JOINT IFRC \& SFA ACTIVITIES}

The Hanford IFRC has been collaborating with the PNNL SFA to perform in-situ biogeochemistry experiments in select IFRC wells that are not localized to the upper aquifer. These wells include the deep microbiology characterization borehole (see Figure 12), and wells 2-23 and 2-24. The research target is the Hanford-Ringold contact, the redox transition zone immediately below, and a deeper anoxic sediment sequence in the core of the Ringold Formation. Laboratory characterization measurements have previously provided a census of the microbial community and insights on sediment redox status and biomineral phases containing Fe. The deployment of a multi-level diffusion sampler (see right hand panel) has enabled solute and gas sampling in groundwater across the various interfaces which has defined the existence of multiple terminal electron accepting processes mediated by micro-organisms. These include sulfate reduction (Figure 12) that is pronounced at the upper and lower anaerobic boundaries. Nitrate, Mn (IV), and Fe(III) reduction occurs immediately and sequentially above the zone of sulfate reduction. Gas sampling results define a diffusive flux of methane and hydrogen gas emanating from reduced, fine-grained Ringold sediments into the U(VI) plume in the Hanford formation with as yet undocumented biogeochemical results.

Continuing research seeks to correlate groundwater redox parameters with sediment Fe and $\mathrm{Mn}$ mineralogy, microbiologic population and functional traits, and hydrologic dynamics, and to integrate these into a reactive biogeochemical transport model. Critical science questions pertain to the energy source that drives microbiological processes, presumed to be heterogeneously distributed organic matter, and the role of hydrologic coupling with the river whose effects are markedly different at this depth then within the more transmissive sediments of the plume.

\section{GEOPHYSICAL MONITORING OF INFILTRATION AND RIVER WATER INTRUSION}

A surface ERT line was installed across the IFRC site during the winter months of 2010 to 2011 to evaluate the feasibility of monitoring precipitation infiltration and transport through the vadose zone. 
These measurements were highly successful during the wet 2010-2011 winter, indicating that infiltration through the backfill and U-enriched vadose zone reached groundwater. There are profound implications of this recharge to U(VI) mass balance in the plume. The results indicated that the analysis would be more robust, and publishable, if two surface lines were monitored rather than one. A two-line surface ERT system over the south eastern half of the IFRC site and a small weather station (temperature and precipitation) were consequently installed in November 2011 to monitor local winter precipitation and infiltration. Previous groundwater monitoring studies during spring high water have indicated that vadose zone recharge of $\mathrm{U}(\mathrm{VI})$ occurs in this quadrant of the well field. The ERT monitoring is being supported by weekly cross-hole radar surveys and neutron logging in 6 wells during the winter months of 20112012. While fall 2011 and early winter of 2012 were dry in Richland, late January and February have been moist providing optimism that the experiment may be successful. This lull in precipitation, however, has enabled the team to install a couple of additional shallow piezometers that will be used to calibrate the ERT system with neutron moisture measurements. Monitoring will continue through May 2012 with hopes that rain will continue to fall.

The SBR funded project led by Rutgers University to study groundwater-river water interaction at the 300 area recently demonstrated the capability of time-lapse ERT to detect river water intrusion into the 300 area. This capability is based on the salinity contrast between river water and groundwater, which is discernible to ERT measurements. ERT monitoring was executed using a 3D surface ERT array during the winter months when stage is low and variations are modest, and revealed a zone of active exchange associated with the paleochannel east of the IFRC site. Based on this effort, it was postulated that such preferred flow pathways into the 300 Area could be imaged using ERT arrays positioned to detect river water intrusion further inland during spring high stage.

To demonstrate this, a three-line surface ERT array was installed between the IFRC site and the Columbia River at the end of April to monitor river water intrusion and retreat during and after spring high stage, specifically focusing on the paleochannel east of the IFRC well field. Data were collected continuously, providing four full ERT data sets per day through the end of August. A set of groundwater monitoring wells that were distributed within the ERT array were continuously monitored for specific conductivity (which varies with river water mixing ratio) to provide ground truth for the surface electrical measurements. The geophysical data collected were of high quality, revealing marked sensitivity to stage induced changes in subsurface conductivity associated with the intrusion of resistive (lower salinity) river water, and also to variations in water table elevation. The data posed initial challenges for time-lapse ERT imaging because of the complex temporal dynamics associated with the competing effects of water table elevation and river water intrusion. These challenges were eventually surmounted by using specialized constraints to inform the imaging algorithm of the water table elevation, leading to time-lapse images of the heterogeneous intrusion of river water into the near-IFRC subsurface environment. Figure 13 shows the locations of the three surface ERT lines with respect to the IFRC well field and the Rutgers array. The colorscale shows the variation in electrical conductivity observed on June 12, 2010, approximately one week after peak stage. Blue colors denote a decrease in conductivity caused by river water intrusion. Time-lapse snapshots of similar images over monitoring period reveal river water advance and retreat predominantly in the in the region previously identified as a primary paleochannel. 


\section{FUTURE PLANS}

Plans for CY 2012 have been markedly curtailed due to budget cuts, and uncertainty over funding levels for FY 13. Most continuing activities underway as of February 1, 2011 will focus on data assimilation, interpretation, modeling, and publication. Two modest ongoing experimental efforts will soon be brought to close.

\section{Fall 2011 Injection Experiments}

This experiment series was initiated in September 2011 and ran through December 2011. Three separate, and highly successful experiments were performed with high U(VI) groundwater. These were discussed in this report on pages 18-19. Thousands of samples were collected from these experiments that are currently under analysis.

\section{Winter 2011-2012 Infiltration Monitoring}

The two line electrical resistance tomography array that has been installed at the surface of the Hanford IFRC site to quantify winter precipitation infiltration will be monitored through May 2012. Measurements are automatically taken at multiple times daily. Groundwater sampling to determine if there are measureable excursions in groundwater $U$ that correlate with events of vadose zone discharge will be performed if geophysical measurements indicate impending breakthrough to groundwater.

\section{IFRC Microbiology and Biogeochemistry}

Down-hole microbiology research in IFRC wells will continue in collaboration with the PNNL SFA. These studies will emphasize biogeochemical processes in transmissive aquifer sediments above the Hanford-Ringold interface, and within the Ringold aquitard (redox transition zone) using three IFRC wells that allow access to these zones.

\section{Select Publications Targeted for FY 2011}

1.) Hydrophysical structural model for the IFRC vadose zone and saturated zone based on electrical resistance tomography.

2.) Statistical analysis of multiple year passive monitoring data of $U$ mobilization to identify system scale controlling variables.

3.) A biogeochemical model for the abrupt redox transition zone present below the Hanford-Ringold contact: Energy sources and reaction network.

4.) An experiment-based kinetic model for $U$ release from 300 A periodically wetted zone sediments.

5.) A model simulation study of hydrologic-geochemical coupling in the periodically rewetted lower vadose zone and effects of hydrologic variations.

6.) Effects of sequential data assimilation on hydrogeologic model uncertainty. 
7.) Effect of geochemical heterogeneity and dynamic hydrologic conditions on U plume migration in the groundwater-river interaction zone.

\section{CHALLENGES AND CONCERNS}

Given the abrupt planned termination of the IFRC project at the end of FY 12, a major concern is the receipt of sufficient funding in FY 13 to allow the completion and publication of one-of-a-kind, worldclass experiments performed in the groundwater-river interaction zone in FY 2011 and FY 2012. Resources have been redirected in the last half of FY 2012 to support this important activity, but funding levels and time are inadequate for completion. Important data sets and modeling will remain unpublished at the end of FY 2012. The inability to publish high-quality results that have resulted from staff, postdoc, and student time investments will detrimentally affect their careers. A summary publication of all that has been learned at this unique and dynamic site would be a desired and impactful cap-stone objective.

\section{POSTERS, PRESENTATIONS, AND PUBLICATIONS}

\section{Presentations}

Carvajal, D. A., A. E. Plymale, A. Konopka, and J. K. Fredrickson (2011) Uranium Toxicity to Native Microbial Communities in the Hanford 300 Area Groundwater. Presented by Denny Carvajal at WM2011, Phoenix, AZ on February 28, 2011.

Chen, X., G. E. Hammond, P. C. Lichtner and M. L. Rockhold (2011) Impacts of Hydrologic and Geochemical Uncertainty on Predicting Uranium Migration at the Hanford 300 Area, American Geophysical Union Fall 2011 Meeting, San Francisco, CA.

Hammond, G. E. (2011) A Benchmark for Physical and Chemical Processes at the Hanford 300 Area. Subsurface Environmental Simulation Workshop, Berkeley, CA.

Hammond, G. E. and X. Chen (2011) Simulation of October 2009 U(VI) Desorption Experiment. Hanford 300 Area IFRC Workshop, Richland, WA on January 19-20, 2011.

Hammond, G. E., X. Chen and P. C. Lichtner (2011) Uncertainty Quantification using High Performance Computing for the October 2009 Uranium Desorption Experiment at the Hanford 300 Area IFRC Site. Presented at the $6^{\text {th }}$ Annual DOE BER SBR PI Meeting, Washington, DC on April 26-28, 2011.

Konopka, A. and J. P. McKinley (2011) Theme Area 3: Field Scale Microbial Ecology \& Biogeochemistry. Presented by James McKinley at the PNNL-BER Briefing for the PNNL SFA, Washington, DC on August 4, 2011.

Konopka, A. (2011) Field Scale Microbial Ecology and Biogeochemistry: Prospective Research FY1216. Presented by Allan Konopka at the Triennial SBR PNNL SFA Review, Richland, WA on March 29, 2011.

Konopka A. (2011) Nature's Pulsing Paradigm. Presented by Allan E Konopka (Invited Speaker) at 3rd Annual Argonne Soil Metagenomics Workshop, Argonne, IL on October 7, 2011. 
Konopka, A. (2011) Theme Area 3 Overview: Field Scale Microbial Ecology \& biogeochemistry. Presented by Allan Konopka at the Triennial SBR PNNL SFA Review, Richland, WA on March 29, 2011.

Lee, J. H., J. K. Fredrickson, X. Lin, R. K. Kukkadapu, M. I. Boyanov, S. M. Heald, A. E. Plymale, D. W. Kennedy, K. M. Kemner, A. Konopka, B. N. Bjornstad, D. A. Moore, C. T. Resch, J. L. Phillips, J. P. McKinley, and J. M. Zachara (2011) Anaerobic Biogeochemical Processes in Hanford 300 Area IFRC Subsurface sediments. Presented by Jim K. Fredrickson at the $6^{\text {th }}$ Annual DOE BER SBR PI Meeting, Washington, DC on April 26-28, 2011.

Lichtner, P, G. Hammond, R. Mills, B. Philip, D. Svyatskiy, G. Bisht, J. Kumar, C. Lu, X. Chen, B. Smith and A. Valocchi (2011) PFLOTRAN: The Next-Generation Peta-Scale Subsurface Reactive Flow and Transport Code, SciDAC 2010, Denver, CO on July 11-14, 2011.

Liu, C. (2011) Upscaling of Geochemical and Biogeochemical Reactions. Presented by Chongxuan Liu (Invited Speaker), International Groundwater Forum 2011, Wuhan, July 14, 2011.

Liu, C., J. Shang, S. N. Kerisit, and J. M. Zachara (2011) Effect of Pore-Scale Process Coupling on Macroscopic Manifestation of Reactions. Presented by Chongxuan Liu (Invited Speaker) at Microbial Community Initiative Workshop at PNNL, Richland, WA on February 7, 2011.

Liu, C., J. Shang, S. N. Kerisit, J. M. Zachara, R. Ma, C. Zheng, J. Greskowiak, and H. Prommer (2011) Importance of Fundamental Processes and Upscaling to Reactive Transport Prediction. Presented by Chongxuan Liu (Invited Speaker) at Fragrant Hill Workshop on Tackling China's Groundwater Contamination, organized by China Science and Technology Ministry, Chinese Academy of Science, and China National Science Foundation, Beijing, China on September 27, 2011.

Liu, C., J. Shang, S. N. Kerisit, R. P. Ewing, A. G. Hunt, and J. M. Zachara (2011) Pore-Scale Processes Coupling and Upscaling of Geochemical Reactions. Presented by Chongxuan Liu (Keynote speaker), at IPACES Annual Conference 2011, Guiyang, China, July 8, 2011.

Liu, C., S. N. Kerisit, and J. M. Zachara (2011) Sub-Grid Reactive Diffusion and Apparent Uranyl Adsorption/Desorption Rates. Presented by Chongxuan Liu at AGU 2011 Fall Meeting, San Francisco, CA on December 15, 2011.

Liu, C., S. N. Kerisit, R. P. Ewing, J. Shang, and J. M. Zachara (2011) Pore-Scale Process Coupling and its Effect on the Apparent Rates of Uranyl Surface Complexation. Presented by Chongxuan Liu (Keynote Speaker) at Goldschmidt Conference 2011, Prague, Czech Republic on August 19, 2011.

Ma, R., C. Zheng, J. M. Zachara, M. Tonkin (2011) Using Heat as a Groundwater Tracer for Aquifer Characterization in a Highly Dynamic Flow Environment. Invited presentation at the Geological Society of America annual meeting, Minneapolis, MN.

McKinley, J. P., C. T. Resch, M. D. Miller, R. M. Kaluzny, and J. M. Zachara (2011) The Geology and Geochemistry of the Hanford Site 300 Area. Presented by James P. McKinley at the $6^{\text {th }}$ Annual DOE BER SBR PI Meeting, Washington, DC on April 26-28, 2011.

Murray, C. J., J. M. Zachara, Y. J. Bott, and J. P. McKinley (2011) A Geochemical Heterogeneity Model for a Contaminated Vadose Zone-Aquifer System. Presented by Chris Murray at the $6^{\text {th }}$ Annual DOE BER SBR PI Meeting, Washington, DC on April 26-28, 2011. 
Rockhold, M. L., X. Chen, R. Ramanathan, V. R. Vermeul, T. C. Johnson, and C. J. Murray (2011) Facies Delineation Using Core, Wireline Log, Electrical Resistance Tomography, and Electromagnetic Borehole Flowmeter Data. Presented by Mark L. Rockhold at AGU, San Francisco, CA on December 9, 2011.

Rockhold, M. L., X. Chen, V. R. Vermeul, D. R. Newcomer, T. C. Johnson, C. J. Murray, Y. Rubin, and J. M. Zachara (2011) Facies Delineation Using Core, Borehole Biophysical Log, Electrical Resistivity Tomography, and Electromagnetic Borehole Flow Meter Data. Presented at the $6^{\text {th }}$ Annual DOE BER SBR PI Meeting, Washington, DC on April 26-28, 2011.

Rubin, Y., X. Chen, M. Over, Y. Yang, H. Murakami, G. E. Hammond, M. L. Rockhold, T. C. Johnson and J. M. Zachara (2011) Multi-Scale and Multi-Type Data Assimilation for Hydrogeological Characterization at the Hanford 300 Area. Presented at the $6^{\text {th }}$ Annual DOE BER SBR PI Meeting, Washington, DC on April 26-28, 2011.

Zachara, J. M., J. K. Fredrickson, H. Bolton, Jr, J. Davis, A. R. Felmy, G. E. Hammond, K. M. Kemner, A. Konopka, C. Liu, M. J. Marshall, J. P. McKinley, C. J. Murray, C. I. Pearce, D. Richardson, E. E. Roden, K. M. Rosso, T. D. Scheibe, L. Shi, M. J. Wilkins, B. D. Wood, and C. Zhang (2011) Role of Microenvironments and Transition Zones in Subsurface Reactive Contaminant Transport: The PNNL SFA. Presented by John M. Zachara and Jim K. Fredrickson at the $6^{\text {th }}$ Annual DOE BER SBR PI Meeting, Washington, DC on April 26-28, 2011.

Zachara, J. M., M. D. Freshley, B. N. Bjornstad, J. N. Christensen, M. E. Conrad, J. K. Fredrickson, G. E. Hammond, R. Haggerty, T. C. Johnson, D. B. Kent, A. Konopka, P. C. Lichtner, C. Liu, J. P. McKinley, C. J. Murray, M. L. Rockhold, Y. Rubin, V. R. Vermeul, R. J. Versteeg, C. Zheng, and K. M. Thompson (2011) OVERVIEW: Multi-Scale Mass Transfer Processes Controlling Natural Attenuation and Engineered Remediation: An IFRC Focused on Hanford's 300 Area Uranium Plume. Presented by John M. Zachara (Invited Speaker) at the $6^{\text {th }}$ Annual DOE BER SBR PI Meeting, Washington, DC on April 2628, 2011.

Zachara, J. M., M. D. Freshley, B. N. Bjornstad, J. N. Christensen, M. S. Conrad, J. K. Fredrickson, G. E. Hammond, R. Haggerty, T. C. Johnson, D. B. Kent, A. Konopka, P. C. Lichtner, C. Liu, J. P. McKinley, C. J. Murray, M. L. Rockhold, Y. Rubin, V. R. Vermeul, R. J. Versteeg, C. Zhang, and K. M. Thompson (2011) OVERVIEW: Multi-Scale Mass Transfer Processes Controlling Natural Attenuation and Engineered Remediation: An IFRC Focused on Hanford's 300 Area Uranium Plume. Presented by John M. Zachara at the Triennial SBR PNNL SFA Review, Richland, WA on March 30, 2011.

Zachara, J. M., M. D. Freshley, B. N. Bjornstad, J. N. Christensen, M. S. Conrad, J. K. Fredrickson, G. E. Hammond, R. Haggerty, T. C. Johnson, D. B. Kent, A. Konopka, P. C. Lichtner, C. Liu, J. P. McKinley, C. J. Murray, M. L. Rockhold, Y. Rubin, V. R. Vermeul, R. J. Versteeg, C. Zhang, and K. M. Thompson (2011) OVERVIEW: Multi-Scale Mass Transfer Processes Controlling Natural Attenuation and Engineered Remediation: An IFRC Focused on Hanford's 300 Area Uranium Plume. Presented by John M. Zachara (Invited Speaker) at the $6^{\text {th }}$ Annual DOE BER SBR PI Meeting, Washington, DC on April 26$28,2011$.

Zachara, J. M., M. D. Freshley, B. N. Bjornstad, J. N. Christensen, M. S. Conrad, J. K. Fredrickson, G. E. Hammond, R. Haggerty, T. C. Johnson, D. B. Kent, A. Konopka, P. C. Lichtner, C. Liu, J. P. McKinley, C. J. Murray, M. L. Rockhold, Y. Rubin, V. R. Vermeul, R. J. Versteeg, C. Zhang, and K. M. Thompson (2011) Multi-Scale Mass Transfer Processes Controlling Natural Attenuation and Engineered Remediation: An IFRC Focused on Hanford's 300 Area Uranium Plume. Presented by John M. Zachara at the $6^{\text {th }}$ Annual DOE BER SBR PI Meeting, Washington, DC on April 26-28, 2011. 
Zachara, J. M., J. A. Davis, P. E. Long, K. H. Williams, M. D. Freshley, and J. P. McKinley (2011) Persistence of Uranium Groundwater Plumes: Contrasting Mechanisms at Two Contaminated DOE Sites. Presented by John M. Zachara at GSA Annual Meeting, Minneapolis, MN on October 10, 2011.

Zheng, C. (2011) Model Complexity: A Personal Odyssey. Invited presentation at the Geological Society of America annual meeting, Minneapolis, MN.

\section{Publications}

$\underline{2012}$

Chen, X., H. Murakami, M. Hahn, G. E. Hammond, M. Rockhold, Y. Rubin, and J. Zachara (2012) Three-dimensional Bayesian geostatistical aquifer characterization at the Hanford 300 Area using tracer test data. Water Resources Research (accepted).

De Barros, F. P. J., S. Ezzedine, and Y. Rubin (2012) Impact of hydrogeological data on measures of uncertainty, site characterization and environmental performance metrics. Advances in Water Resources (in press).

Ewing, R. P., C. Liu, and Q. H. Hu (2012) Modeling intragranular diffusion starting from nonequilibrium. Water Resources Research (submitted).

Johnson T. C. (2012) A hybrid stochastic-deterministic approach for sampling highly parameterized inverse solutions constrained by noisy data and uncertain geostastistics. Geophysical Journal International (submitted).

Johnson, T. C., R. Versteeg, A. Ward, J. W. Greenwood, and C. Strickland (2012) Electrical geophsical characterization of the Hanford 300 Area Intergrated Field Research Challenge wellfield using high performance DC resistivity inversion geostatistically constrained by borehole conductivity logs. Geostatistics (soon to be submitted).

Lichtner, P. C. and G. E. Hammond (2012) Using high performance computing to understand roles of labile and nonlabile U(VI) on Hanford 300 Area plume longevity. Vadose Zone Journal (submitted).

Lin, X., D. Kennedy., J. Fredrickson, B. Bjornstad, and A. Konopka (2012) Vertical stratification of subsurface microbial community composition across geological formations at the Hanford Site. Environmental Microbiology DOI: 10.1111/j.1462-2920.2011.02659.x (in press).

Lin, X., D. Kennedy, A. Peacock, J. McKinley, C. T. Resch, J. Fredrickson, and A. Konopka (2012) Distribution of microbial biomass and potential for anaerobic respiration in Hanford Site 300 Area subsurface sediment. Applied and Environmental Microbiology 78, 759-767.

Liu, C., S. Kerisit, J. Shang, and J. Zachara (2012) Scale dependent rates of uranyl desorption from contaminated sediments: Role of pore-scale reactive mass transfer. Environmental Science \& Technology (submitted).

Zachara, J., M. D. Freshley, J. A. Davis, K. Williams, P. Long, J. P. McKinley, S. Yabusaki, M. Rockhold, C. Liu, J. Fredrickson, A. Konopka, J. Bargar, and P. Fox (2012) Persistence of uranium groundwater plumes: Contrasting mechanisms at two contaminated DOE sites. Journal of Contaminant Hydrology (soon to be submitted). 
Ma, R., C. Liu, J. Greskowiak, H. Prommer, C. Zheng, and J. Zachara (2012) Influence of calcite on uranyl reative transport in the grounwater-river mixing zone. Environmental Science \& Technology (accepted).

Ma, R., C. Zheng, and C. Liu (2012) Groundwater impacts of radioactive wastes and associated environmental modeling assessment. Encyclopedia of Sustainability Science and Technology (in press).

Ma, R., C. Zheng, J. Zachara, and M. Tonkin (2012) Utility of bromide and heat tracers for aquifer characterization in a highly dynamic environment. Water Resources Research (in press).

McKinley, J. P., J. Zachara, C. T. Resch, R. M. Kaluzny, M. D. Miller, V. R. Vermeul, B. Fritz, and J. Moser (2012) River water intrusion and contaminant uranium contributions to groundwater during the annual spring rise in Columbia River stage at the Hanford Site 300 Area, Washington. Environmental Science \& Technology (submitted).

Murakami, H., X. Chen, and Y. Rubin (2012) Sequential Bayesian geostatistical inversion and evaluation of combined data worth for aquifer characterization at the Hanford 300 Area. (in preparation).

Murray, C., J. Zachara, J. P. McKinley, A. Ward, K. Draper, and D. Moore (2012) Establishing a geochemical model for a contaminated vadose zone - aquifer system. Journal of Contaminant Hydrology (in press).

Nowak, W., Y. Rubin, and F. P. J. De Baros (2012) A hypothesis-driven approach to optimal site investigation. Water Resources Research (in press).

Revil, A., M. Karaoulis, T. Johnson, and A. Kemna (2012) A review of low-frequency electrical methods for subsurface characterization and monitoring in hydrogeology. Hydrogeology Journal (submitted).

Sheng, P., Q. Hu, R. Ewing, C. Liu, and J. Zachara (2012) Quantitative 3-D elemental mapping by LAICP-MS of basalt from the Hanford 300 Area. Environmental Science \& Technology (in press).

Stoliker, D. L., C. Liu, D. Kent, and J. Zachara (2012) Size dependence of desorption kinetics and equilibrium adsorption on uranium(VI)-contaminated sediments. Water Resources Research (in preparation).

Yin, J., R. Haggerty, M. Rockhold, and D. Kent (2012) U(VI) desorption in groundwater during water table fluctuations. Journal of Contaminant Hydrology (in preparation).

Zachara, J., C. Liu, M. Oostrom, J. P. McKinley, T. Wietsma, and C. T. Resch (2012) Mass transfer limited adsorption and desorption of $\mathrm{U}$ in intact sediment cores retrieved from a contaminated aquifer. Environmental Science \& Technology (submitted).

$\underline{2011}$

De Barros, F. P. J. and Y. Rubin. (2011) Modelling of block-scale macrodispersion as a random function. Journal of Fluid Mechanics 676, 514-545.

Greskowiak, J., M. Hay, H. Prommer, C. Liu, V. Post, R. Ma, J. Davis, C. Zheng, and J. Zachara (2011) Simulating adsorption of U(VI) under transient groundwater flow and hydrochemistry: Physical versus chemical nonequilibrium model. Water Resources Research 47. 
Hammond, G. E., P. C. Lichtner, and M. Rockhold (2011) Stochastic simulation of uranium migration at the Hanford 300 Area. Journal of Contaminant Hydrology 120-21, 115-128.

Hay, M. B., D. Stoliker, J. Davis, and J. Zachara (2011) Characterization of the intragranular water regime within subsurface sediments: Pore volume, surface area, and mass transfer limitations. Water Resources Research 47.

Liu C. X., J. Y. Shang, and J. M. Zachara (2011) Multispecies diffusion models: A study of uranyl species diffusion. Water Resources Research 47.

Ma, R., C. M. Zheng, M. Tonkin, and J. M. Zachara (2011) Importance of considering intraborehole flow in solute transport modeling under highly dynamic flow conditions. Journal of Contaminant Hydrology $123,11-19$.

Shang, J. Y., C. X. Liu, Z. M. Wang, and J. Zachara (2011) Effect of grain size on uranium(VI) surface complexation kinetics and adsorption additivity. Environmental Science \& Technology 45, 6025-6031.

Spane, F. A. and R. D. Mackley (2011) Removal of river-stage fluctuations from well response using multiple regression. Ground Water 49, 794-807.

Stoliker, D. L., D. B. Kent, and J. M. Zachara (2011) Quantifying differences in the impact of variable chemistry on equilibrium uranium(VI) adsorption properties of aquifer sediments. Environmental Science \& Technology 45, 8733-8740.

Vermeul, V. R., J. P. McKinley, D. R. Newcomer, R. Mackley, and J. Zachara (2011) River-induced flow dynamics in long-screen wells and impact on aqueous samples. Ground Water 49, 515-524.

Wang, Z. M., J. Zachara, J. Boily, Y. Xia, C. T. Resch, D. A. Moore, and C. Liu (2011) Determining individual mineral contributions to U(VI) adsorption in a contaminated aquifer sediment: A fluorescence spectroscopy study. Geochimica et Cosmochimica Acta 75, 2965-2979.

Yin, J., R. Haggerty, D. Stoliker, D. Kent, J. Istok, J. Greskowiak, and J. Zachara (2011) Transient groundwater chemistry near a river: Effects on U(VI) transport in laboratory column experiments. Water Resources Research 47. 


\section{FIGURES AND ILLUSTRATIONS}

a.) With recent (2011) EBF measurements

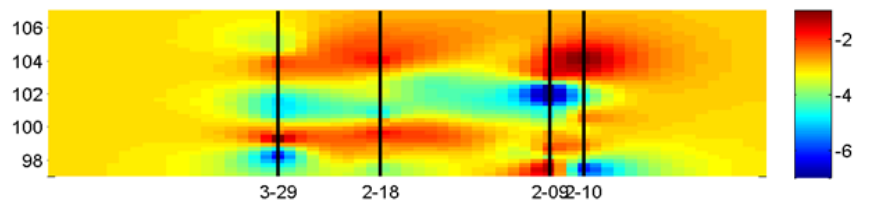

b.) With earlier (2009) EBF measurements

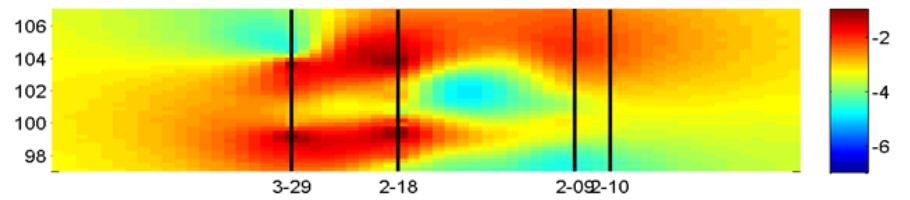

Figure 1. The conditional mean of the log conductivity: a comparison between the previous and current EBF profiles. The cross section goes through the center of the IFRC site from the SE (3-29, left) to the NW (2-10, right). 


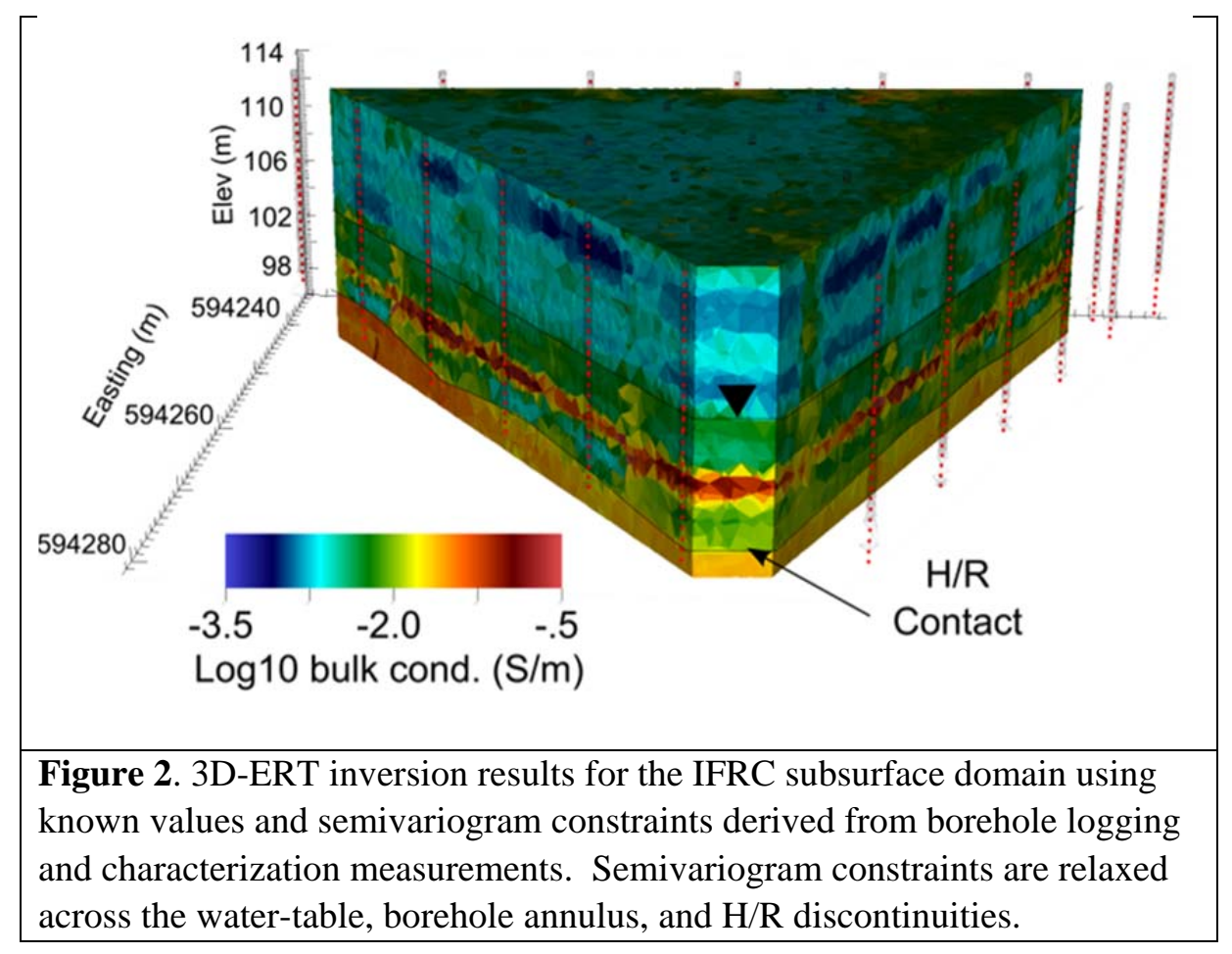




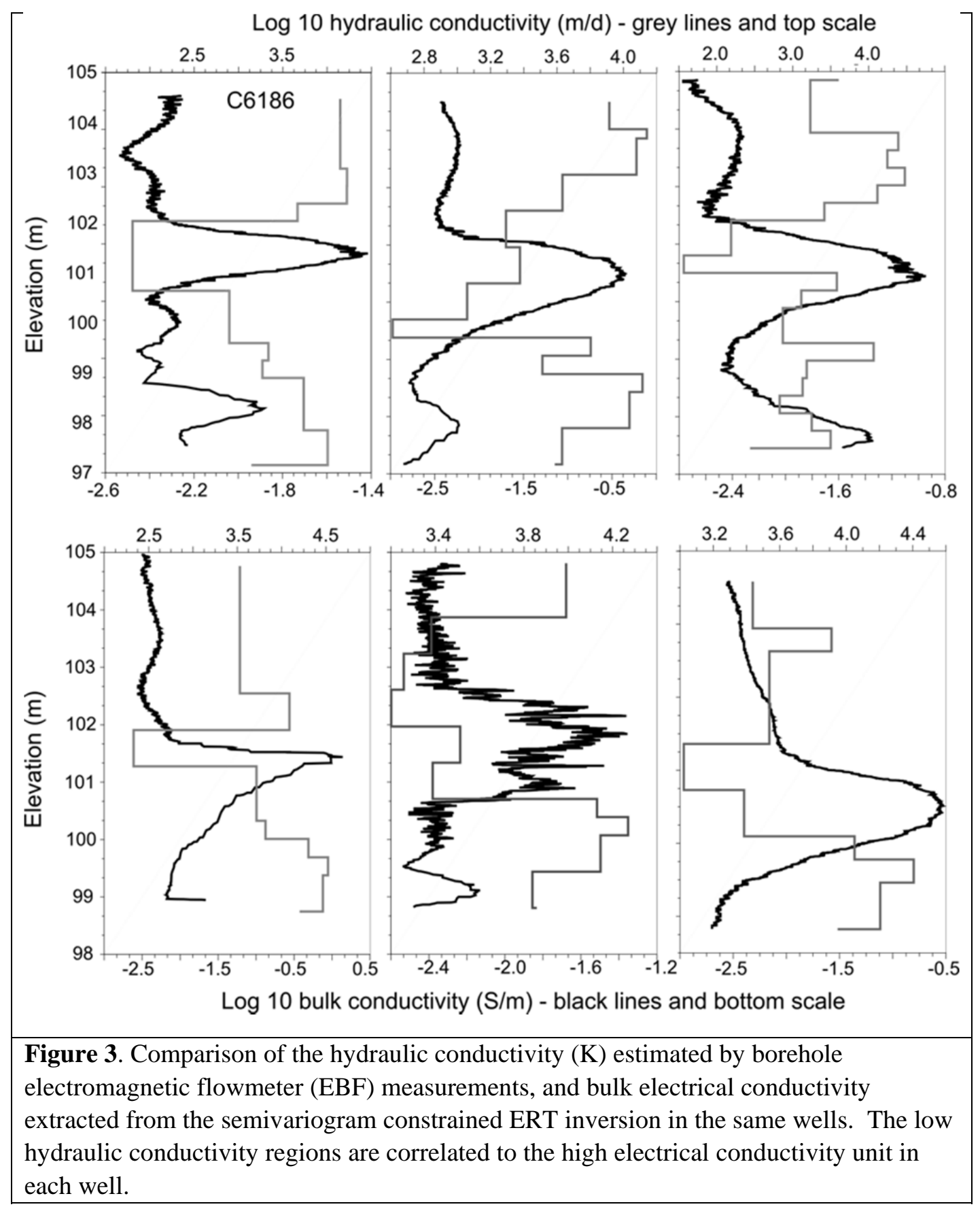



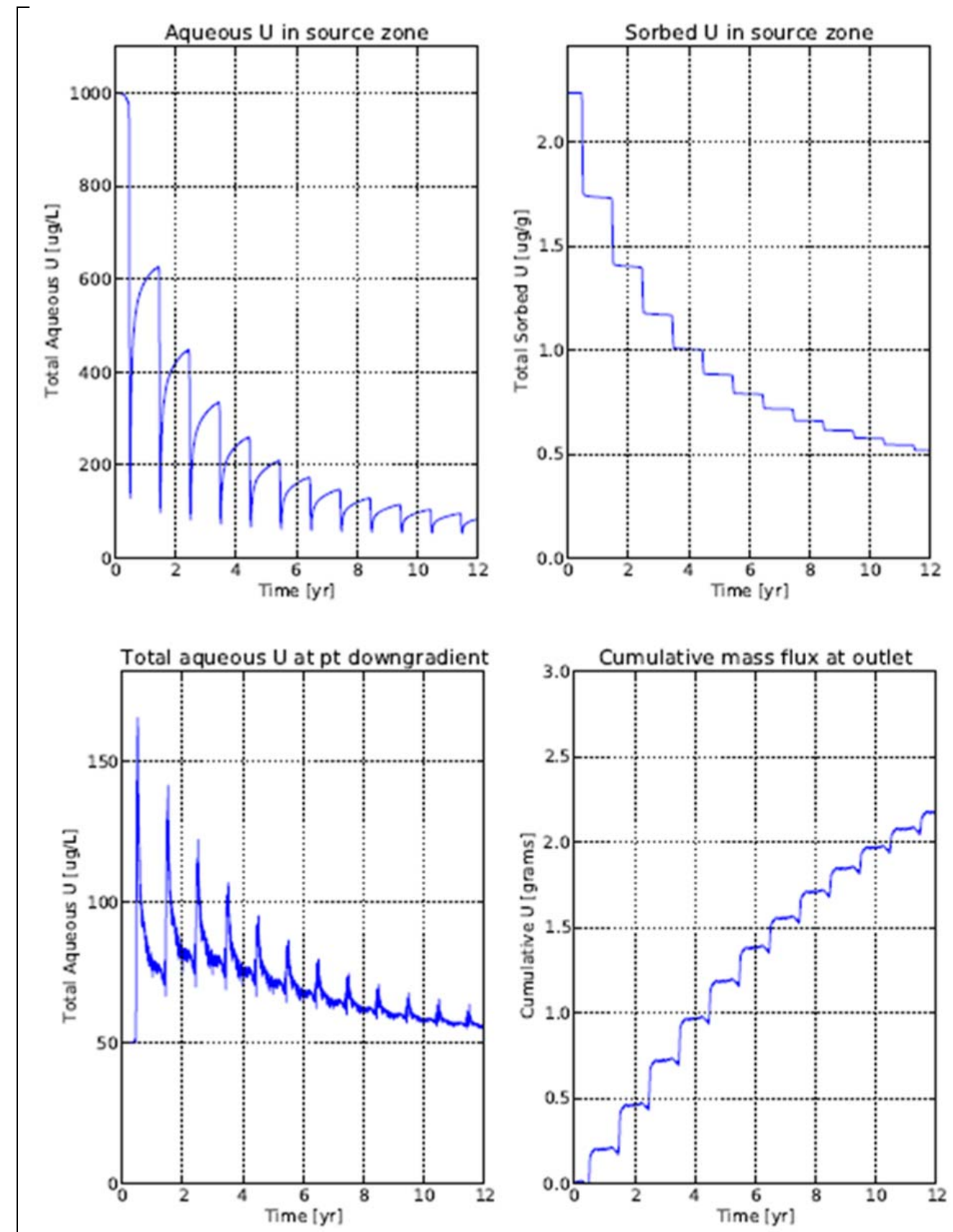

Figure 4. PFLOTRAN modeling of smear zone point contributions to $300 \mathrm{~A}$ groundwater as it occurs near well 3-30 in the IFRC well field. Reaction parameters derived from multi-investigator experimental studies of the smear zone composite. The multi-year simulations used hydrologic data from water year 2010 only. Top left - dissolved U(VI) in unsaturated smear zone pore waters; top right - sorbed U(VI) in the smear zone; Bottom left - Dissolved U(VI) in upper aquifer groundwater: and bottom right - cumulative flux in downstream groundwater. 


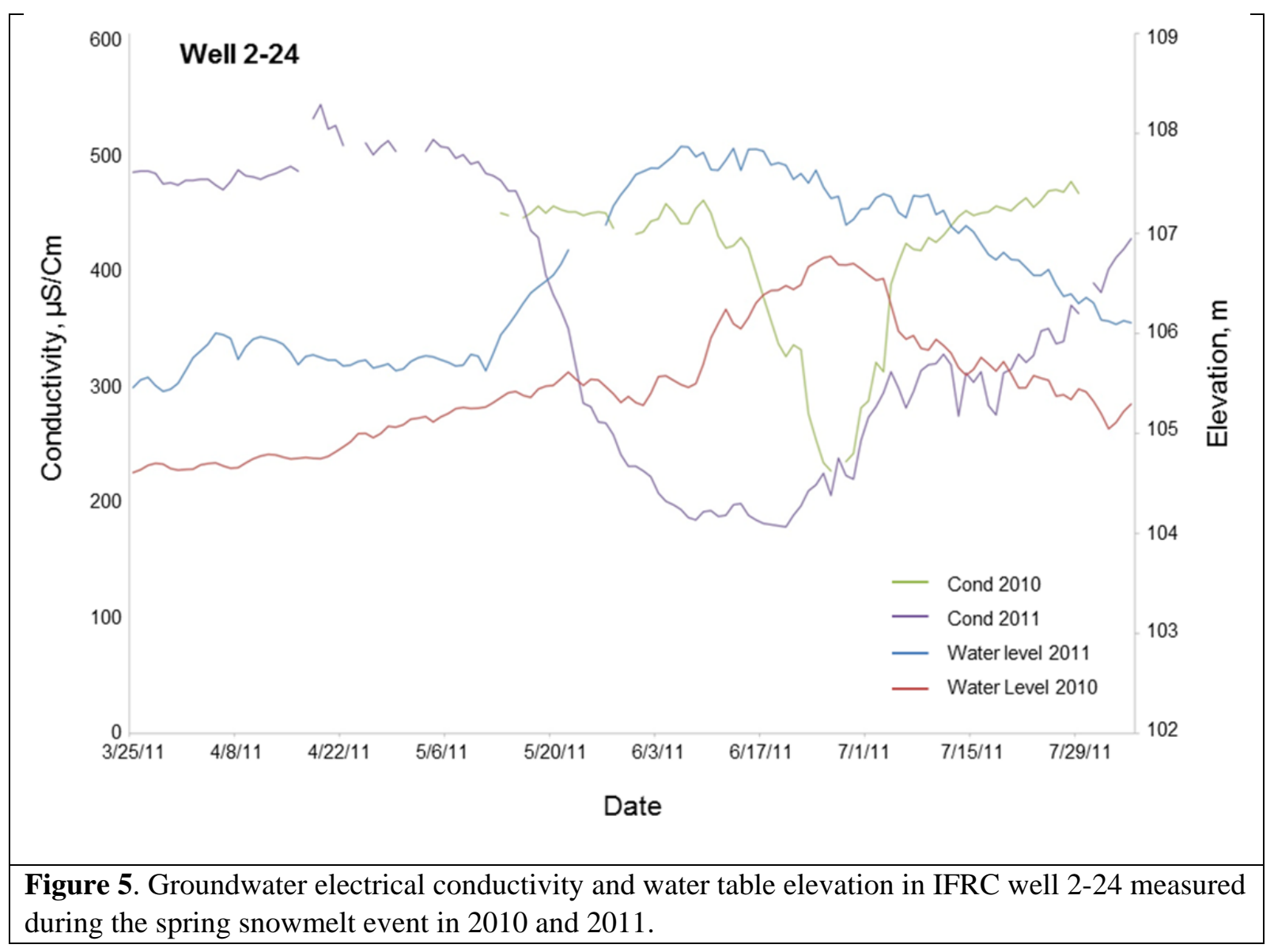




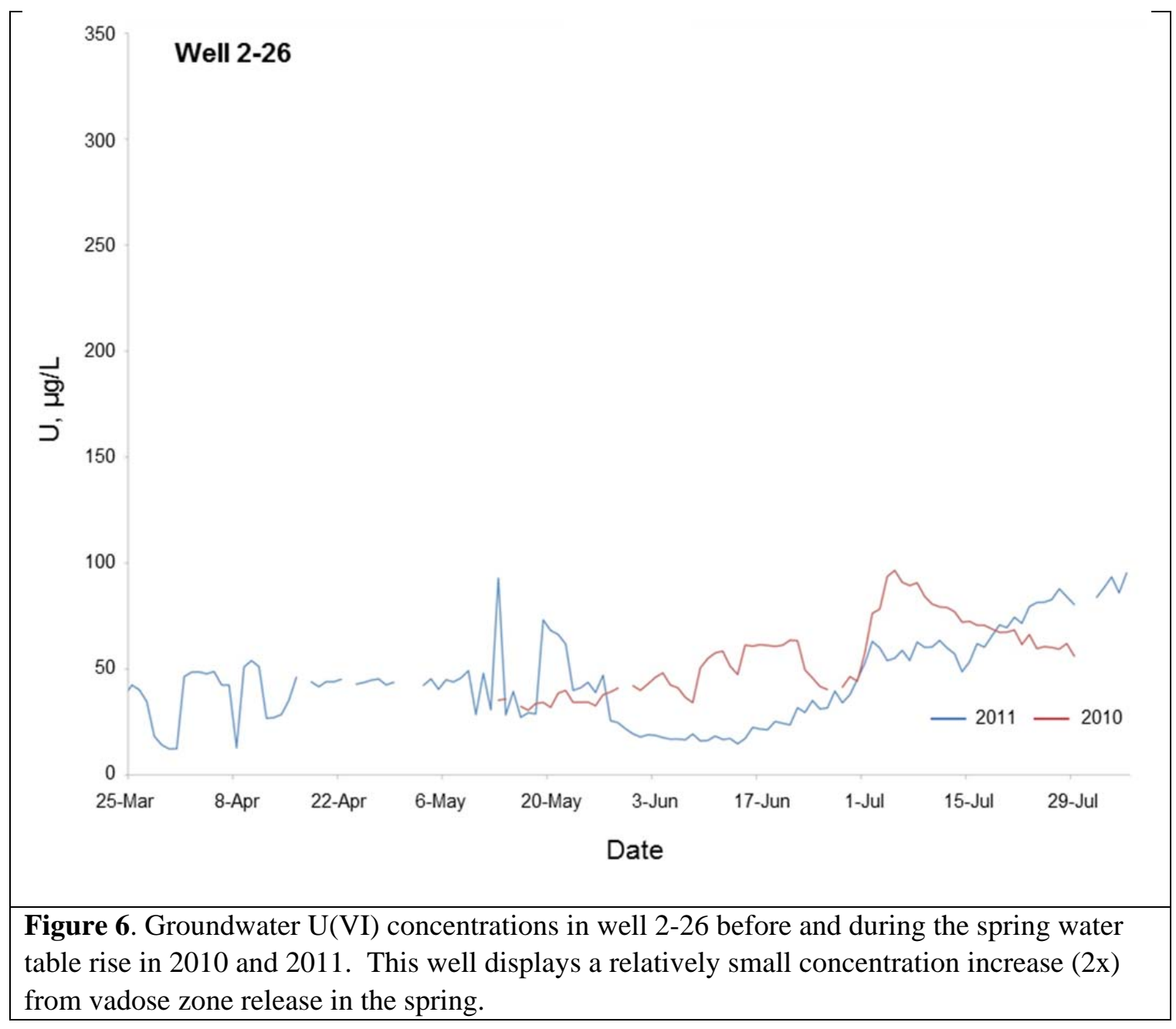




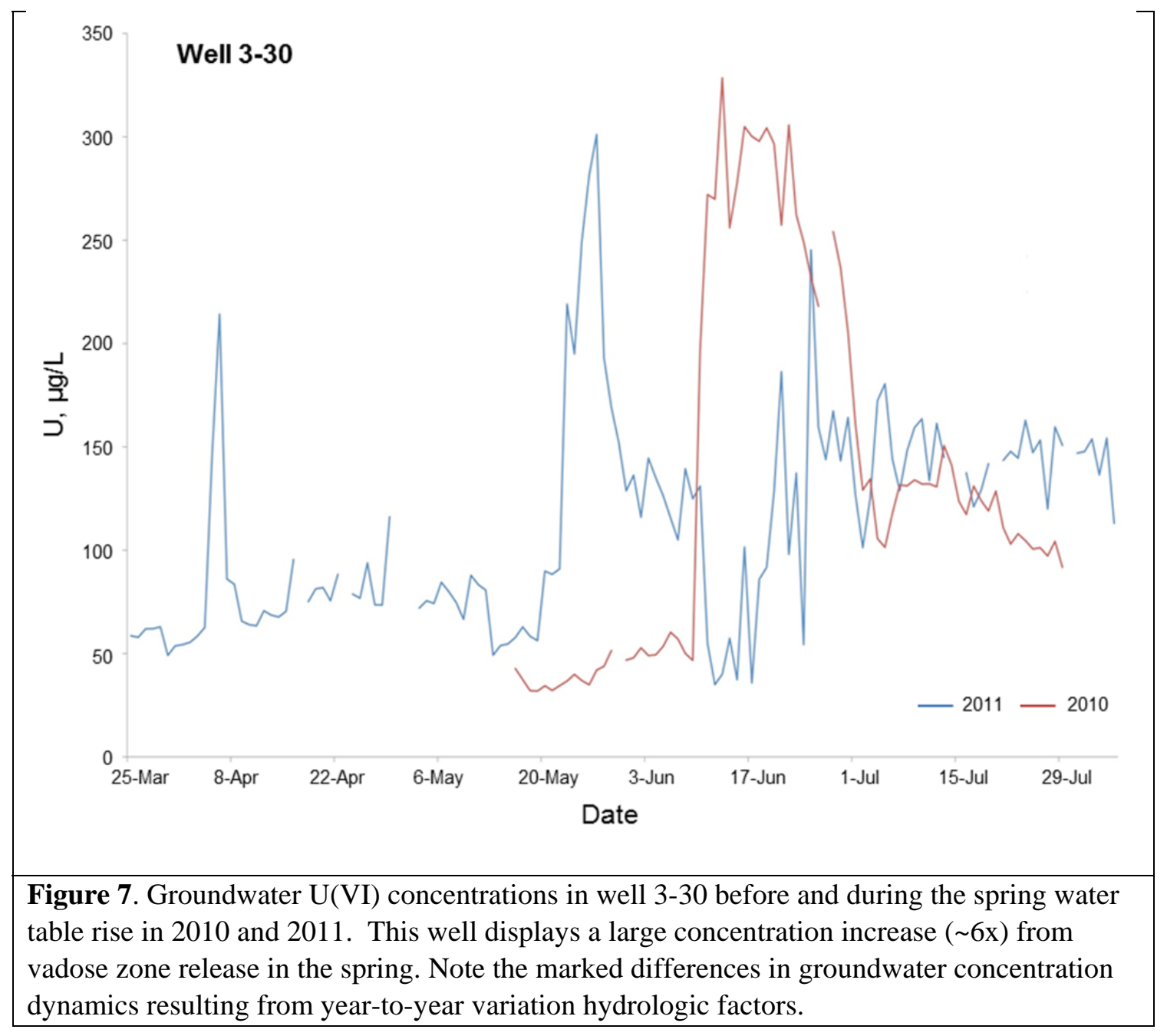









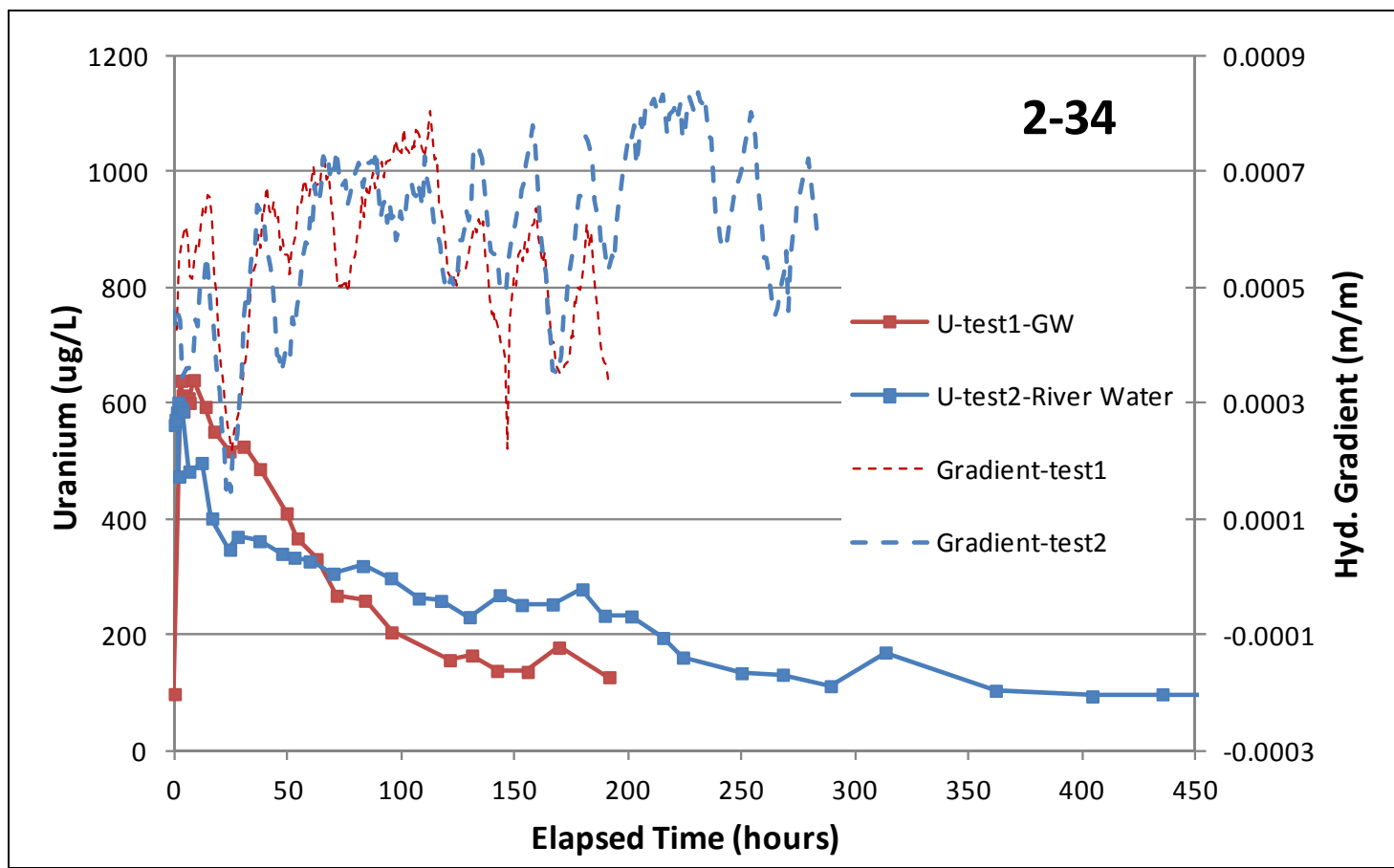

Figure 9. Measured U(VI) concentrations and hydraulic gradient for IFRC well 2-24 in the Fall 2011 high uranium injection experiments. U-test1 (red) utilized 300 A groundwater as the carrier and U-test2 (blue) used filtered river water as the carrier. River water has $25 \%$ of the dissolved bicarbonate of groundwater leading to greater retardation and tailing of the river water plume. 


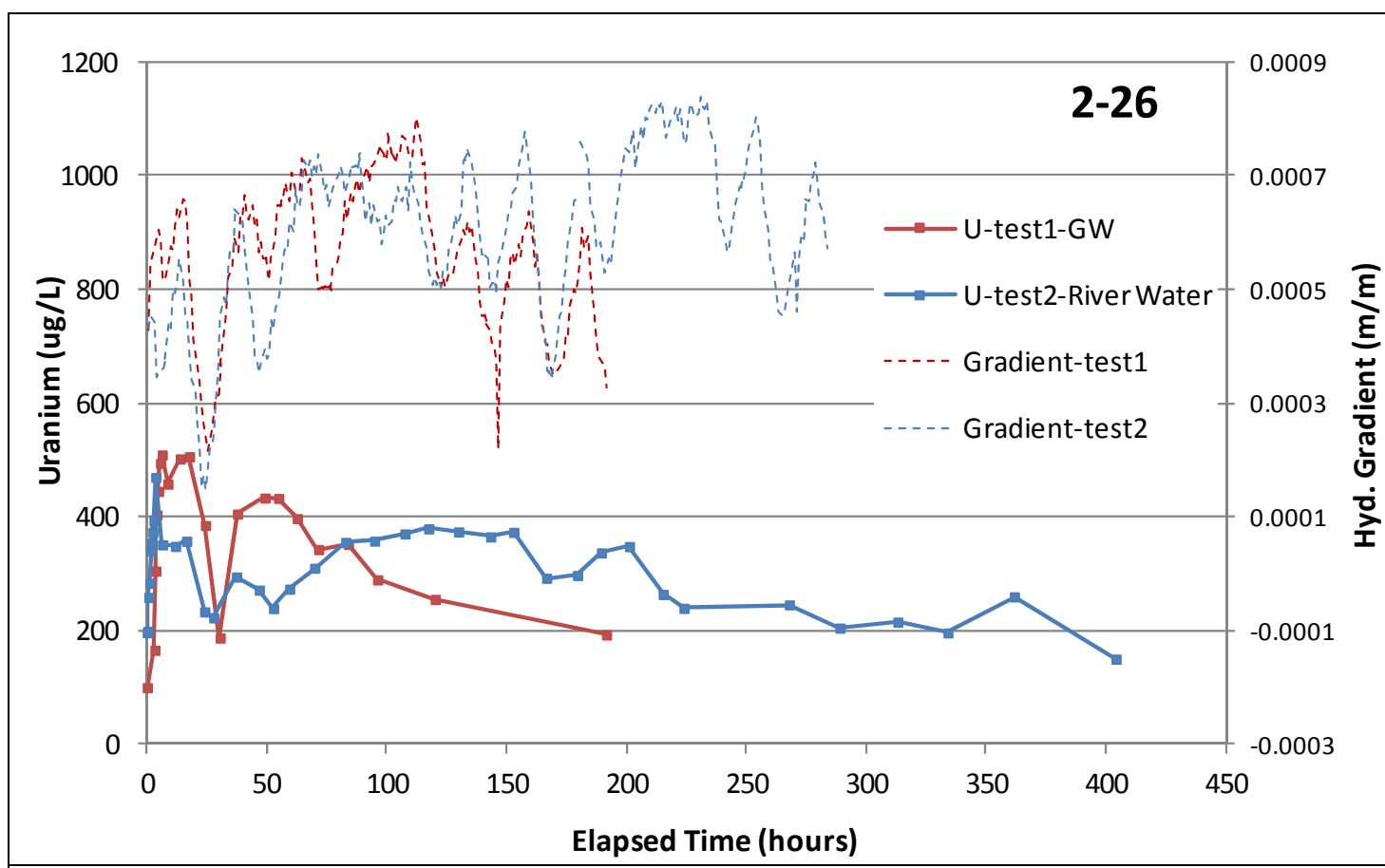

Figure 10. Measured U(VI) concentrations and hydraulic gradient for IFRC well 2-26 in the Fall 2011 high uranium injection experiments. U-test1 (red) utilized 300 A groundwater as the carrier and U-test2 (blue) used river water as the carrier. Note the strong effect of a gradient reversal after $\sim 24 \mathrm{~h}$ on both breakthrough curves. The elevated concentrations in the blue curve over the red after $75 \mathrm{~h}$ are a result of greater $\mathrm{U}(\mathrm{VI})$ adsorption from the river matrix. 


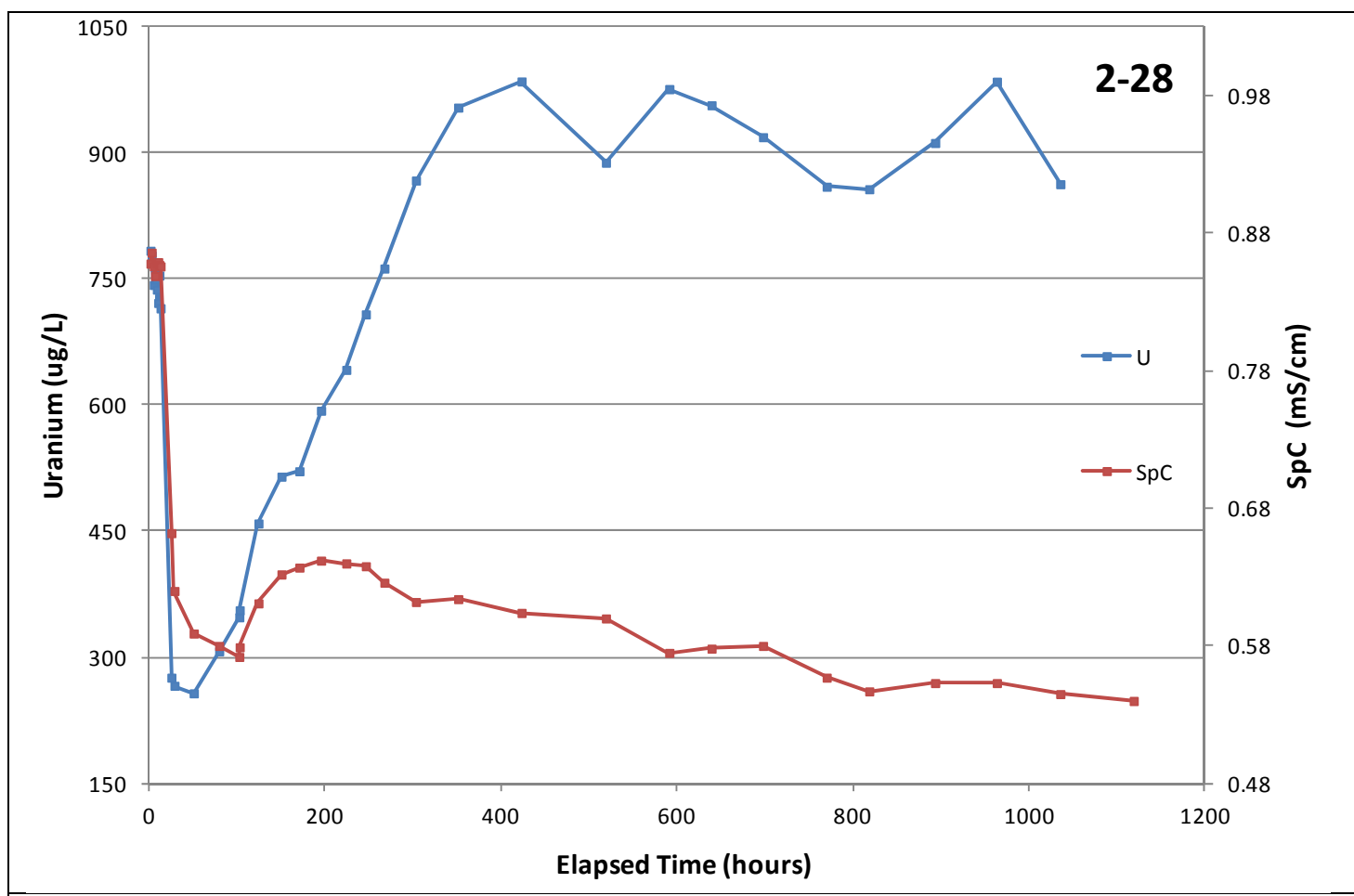

Figure 11. Measured U(VI) concentrations and specific conductance in the third injection experiment performed in the intermediate depth, low K zone (Well 2-28). Filtered river water was used as the carrier. The injected plume has remained in the low $\mathrm{K}$ zone for an unexpected extended time period ( $>42 \mathrm{~d}$ ) with limited mass transfer to under- and over-lying high $\mathrm{K}$ zones. U(VI) concentrations are elevated $(900 \mathrm{ppb})$ over the injected concentration $(750 \mathrm{ppb})$ because returning groundwaters are describing higher concentrations of adsorbed $\mathrm{U}(\mathrm{VI})$ resulting from the river water matrix. 


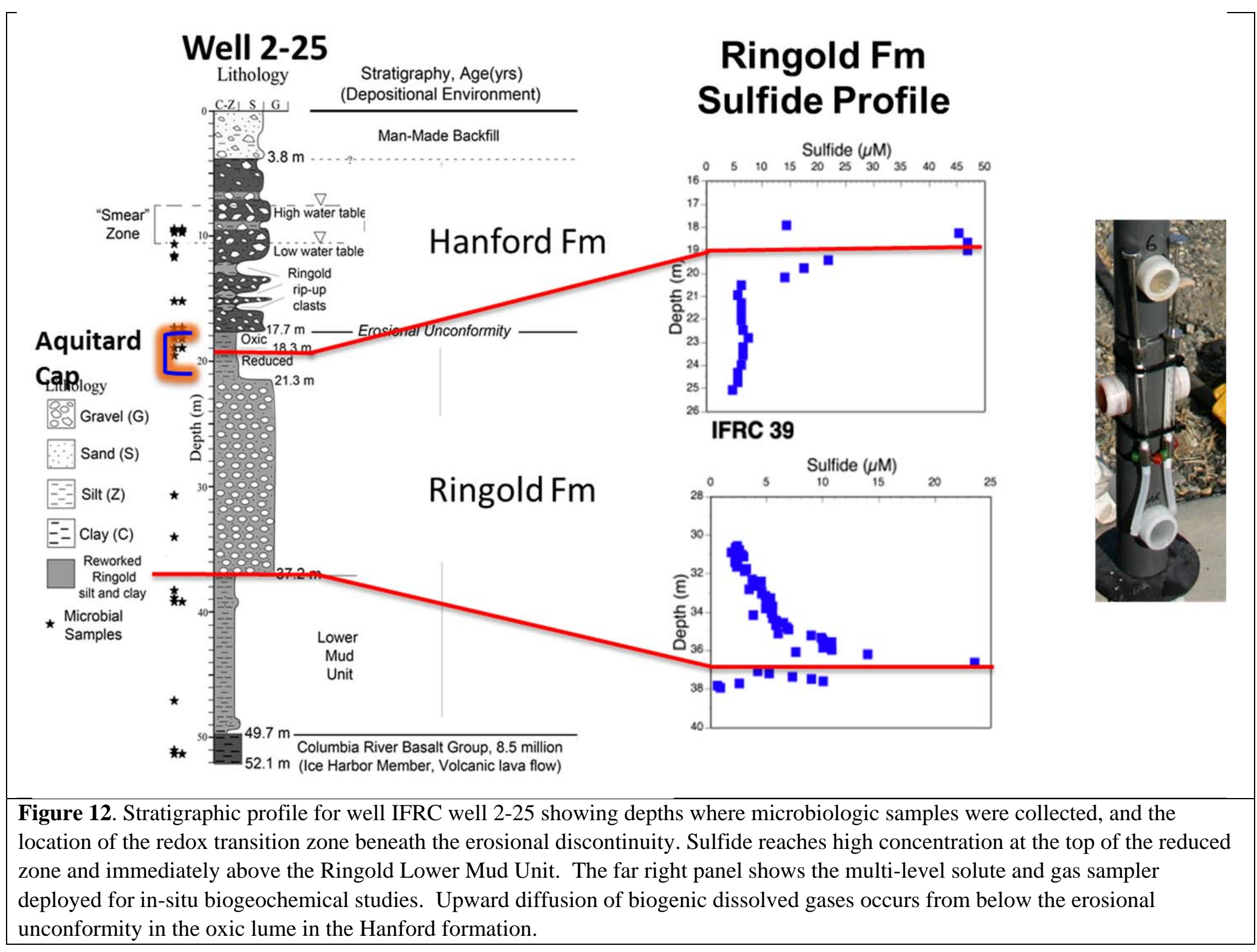




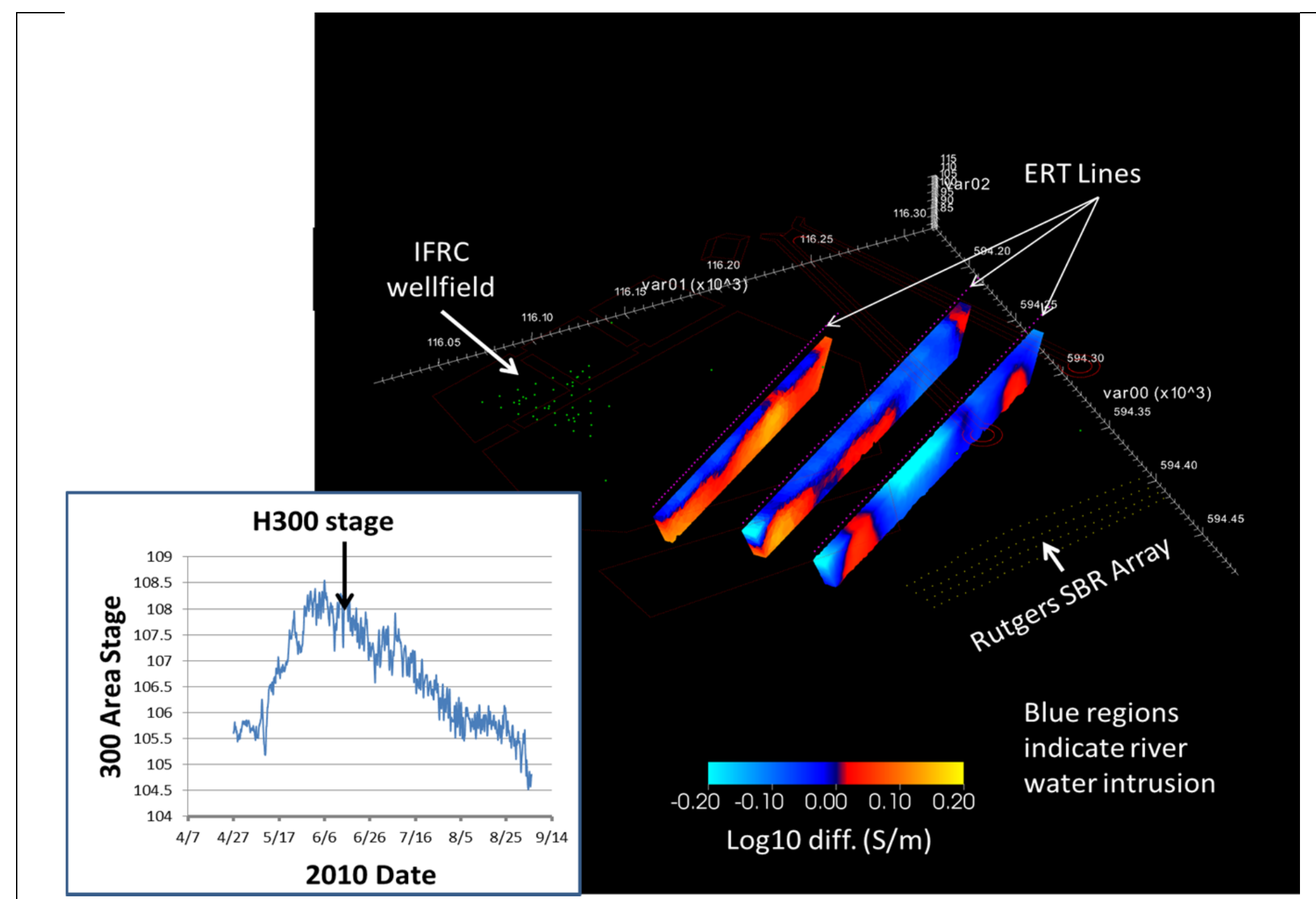

Figure 13. ERT lines used to monitor spring river water intrusion into the IFRC site domain. The location of the Rutgers SBR array is also noted; which lies immediately to the west of the Columbia River. Data is shown for one specific day soon after high river stage. Multiple data sets were collected for each day noted in the blue hydrograph. Blue regions in the ERT profiles denote river water. River water is consequently observed to enter the IFRC site as a vertically thin, upper aquifer plume. 